\title{
İmar Barışının Kentsel Korumaya Yönelik Olumsuz Etkilerinin İstanbul Tarihî Yarımada Perspektifinden İncelenmesi
}

\author{
Investigation of Negative Effects of Zoning Peace on Urban \\ Conservation from the Perspective of Istanbul \\ Historical Peninsula
}

\section{Can Bulubay}

Marmara Üniversitesi Siyasal Bilgiler Fakültesi, Yerel Yönetimler ve Kent Politikaları Anabilim Dalı, İstanbul

\section{ÖZ}

İmar aflarının son sürümü denebilecek İmar Barışı düzenlemesi, 2018'de hayata geçirilmiş, birçok açıdan tartışılmıştır. 06.02.2019'da Kartal'da çöken ve İmar Barışı başvurusu olduğu ortaya çıkan bina ile 26.09.2019'da Silivri'de yaşanan 5.8 büyüklüğündeki deprem, İstanbul'daki yapı stokunun durumunu tartışmalı hâle getirmiştir. Tarihî Yarımada olarak bilinen ve Fatih ilçesinin sınırlarıyla örtüşen bölge, yapı stokunun tarihî ve mimari değeri ile risk durumu nedeniyle kritik önemdedir. Fatih'in büyük bölümünün kanun kapsamında olması, ilçedeki kaçak yapılaşma unsurlarının yasallaşmasını sağlamıştır. Bu, ilçede yaşayanların can güvenliği ile ilçenin tarihî dokusu ve kültürel mirasının devamlılı̆̆ı açısından endişe verici bir durum yaratmıştır. Bu güncel ve kritik durum, makalenin çıkış noktasıdır. İmar Barışı ve kentsel koruma arasındaki çelişkilerin ortaya koyulması ile Tarihi Yarımada'nın kültürel mirasının korunmasıysa makalenin amacı olarak öne çıkarılmış, bu bağlamda kanunun olumsuz etkilerine yönelik tespitler yapılmıştır. Makalenin odak noktasının önemini vurgulamak açısından, planlama ve koruma kavramları arasındaki ilişkiye dair çok sayıda çalışması olan İlhan Tekeli'nin eserlerinden oluşan geniş literatür incelenmiştir. Tekeli'nin kendi uzmanlık alanı olan planlama ve büyük önem verdiğini söylediği kentsel koruma ilgili yorumları derlenmiştir. Bunun yanı sıra kentsel koruma ilke ve uygulamaları ile ilgili literatür incelenmiş ve makalenin teorik altyapısı güçlendirilmiştir. Tarihî Yarımada'nın makale boyunca dikkat çekilmiş mevcut durum ve riskleri ise ilçenin birçok semtindeki sorunlu yapı stoku fotoğraflanarak görünür kılınmıştır. Bundan hareketle çeşitli tespit yapılmış, öneriler sunulmuştur. Bu çalışma ile İmar Barışı'nın, tarihî kent merkezlerinde ve Tarihî Yarımada'da yaratabileceği sorunlara dikkat çekilmesine, bir farkındalık yaratılmasına çalışılmıştır.

Anahtar sözcükler: İmar affı; imar barışı; kentsel koruma, kültürel miras, tarihi yarımada.

\section{ABSTRACT}

The Zoning Peace arrangement, which can be called the last version of zoning amnesties, was implemented in 2018 and was discussed in many ways. The building, which collapsed in Kartal on 06.02.2019 and appeared to be a Zoning Peace application, and the 5.8 magnitude earthquake in Silivri on 26.09.2019 made the status of the building stock in Istanbul controversial. The region, known as the Historical Peninsula and overlapping the borders of Fatih district, is critical due to the historical and architectural value of the building stock and its risk status. The fact that a large part of Fatih is covered by the law has enabled the illegal construction elements in the district to be legalized. This created an alarming situation in terms of the life safety of the residents and the continuity of the historical texture and cultural heritage of the district. This current and critical situation is the starting point of the article. The revealing of the contradictions between Zoning Peace and urban conservation and the preservation of the cultural heritage of the Historic Peninsula were highlighted as the aim of the article, and in this context, the negative effects of the law were determined. In order to emphasize the importance of the focus of the article, extensive literature consisting of the works of Illhan Tekeli, who has many studies on the relationship between the concepts of planning and conservation, has been examined. Tekeli's own expertise, planning and urban conservation comments, which he says gives great importance, have been compiled. In addition, the literature on the principles and practices of urban conservation has been examined and the theoretical infrastructure of the article has been strengthened. The current situation and risks of the Historic Peninsula, which were noticed throughout the article, were made visible by photographing the problematic building stock in many points of the district. Based on this, various determinations were made and suggestions were presented. With this study, it was tried to draw attention to the problems that Zoning Peace may cause in historical city centers and the Historical Peninsula, and to create an awareness.

Keywords: Zoning amnesty; zoning peace; urban conservation; cultural heritage; historical peninsula. 


\section{Giriş}

Türkiye, kentleşme sürecini, gelişmiş ülkelere nazaran geç başlatmış bir ülkedir. Özellikle 2. Dünya Savaşı sonrasındaki dönemde birçok sebepten ötürü kırsal nüfusun azaldığı, kentsel nüfusun ise arttı̆̆ı bir süreç başlamış ve günümüze dek sürmüştür.

Doğum oranlarının artı̧, ölüm oranlarının azalış göstermeye başladığı bu kentleşme sürecinde Keleş'e göre itici güçler, iletici güçler ve çekici güçler olmak üzere üç temel etken grubu tetikleyici olmuştur. İtici güçler, temel olarak köylüyü toprağından ve tarımdan ayrılmaya zorlayan koşullar olup bunlar, tarımda makineleşme, verimin azlığı, toprak sahipliğinin dengesiz dağılımı, yetersiz verim, erozyon, tarım arazilerinin fazla parçalanmış oluşu, başkasının toprağında çalışılması ve buna bağı olarak ortaya çıkan düşük ücret gibi sebepler olarak sıralanabilir. İletici güçler ise ülke çapında görülen hareketliliktir. Bu hareketlilik, haberleşme ve taşıma ağlarının gelişmesi, mal ve hizmet değiş tokuşunun artması, eğitim düzeyinin yükselmesi, yer değiştirmenin kolaylaşması gibi etkenlerden ileri gelmektedir. Çekici güçler ise nüfus akışını kentlere çeken etkenlerdir; sanayileşme, iş olanaklarının artması, kentlerin cazibe merkezleri hâline gelmeleri, çekici güçlerin başlıcalarını oluşturmaktadır (Keleş, 2019, s.67-69).

Kentlerin iç göçler sebebiyle nüfus açısından giderek yoğunlaştığı, kentleşme hızının nüfus artış hızının iki katına ulaştı̆̆ı bir ortamda Tekeli'ye (2009a, s.5) göre gerçekleştirilmesi gereken şey, hızlı bir kentleşme ve sanayileşmedir. Ancak bunun için çok yüksek bir sermaye birikim hızı şarttır ve Türkiye o dönemde böyle bir imkâna sahip değildir. Bu yetersizliğin sonucu olarak da kentlerin çevresini gecekondu kuşaklarının sarması, belli düzeydeki sanayinin ise hava ve su kirliliği yaratması gibi sonuçlar ortaya çıkmıştır. Türkiye gibi çok hızlı kentleşen ve bunu sermaye kıtlığı altında gerçekleştirmeye çalışan ülkeler de kentlerinin oluşumunu denetleyememiş ve gecekondu gibi emrivakilere razı olmak zorunda kalmışır (Tekeli, 2009b, s.3 I7).

Kentlerde görülen nüfus yı̆̆ılması birçok sorunu beraberinde getirmiştir. Demografik yapıların sert ve hızı bir biçimde değişmesi, sosyal ve mekânsal ayrışmaların keskinleşmesi, gecekondu inşalarının kamu arazilerinin haksızca işgal edildiği algısını uyandırması, gecekondu sakinlerinin yaşamlarını insani açıdan asgari düzeyde sürdürmelerini sağlayacak imkânlardan yoksun kalmaları gibi çok sayıda sorun, kentin, kent sakinlerinin, yerel ve merkezî yöneticilerin daima gündeminde olmuştur. Kaçak yapılaşmaya karşı otoritelerin tavrı zaman zaman değişikliğe uğramış, tüm bu sorunların bir şekilde çözülme ihtiyacı da derinden hissedilmiştir. Bu mevcut durumun getirisi olarak da planlı hareket etme, kontrol sağlama, denetimde bulunma gibi amaçlardan hareketle birçok resmî düzenleme yapılmışıtır. 09.05.1985 tarihli ve 3194 saylı İmar Kanunu bu girişimlerin başlıcası olup kanunun I. maddesindeki "yerleşme yerleri ile bu yerlerdeki yapılaşmaların; plan, fen, sağlık ve çevre şartlarına uygun teşekkülünü sağlamak amacıyla düzenlenmiştir" ibaresi, kanunun düzenlenme ve var olma nedenini açıklar niteliktedir. Bunun yanı sıra geçmişte birçok kanun söz konusu sebeplerle hayata geçirilmiş ve uygulanmıştır. 5228 sayılı Bina Yapımını Teşvik Kanunu, 775 sayılı Gecekondu Kanunu, 6306 sayılı Afet Riski Altındaki Alanların Dönüştürülmesi Hakkında Kanun, 5366 sayılı Yıpranan Tarihi ve Kültürel Taşınmaz Varıkların Yenilenerek Korunması ve Yaşatılarak Kullanılması Hakkında Kanun gibi birçok kanun, kentlerdeki yapılaşmayı ve gelişimi düzenlemek, kontrol etmek ve denetlemek gibi amaçlarla hazırlanıp uygulanmıştır.

Yapılan tüm resmî girişim ve uygulamalara karşın gecekondu sorunu, kaçak yapılaşma ve benzeri kanun dışı yollarla kanunlar delinmiş, planlara uyulmamıştır. Sorunlar karşısında yerel ve merkezî yönetimler yetersiz kalmış, devamında tekrarlayan bir şekilde imar afları gündeme gelmiştir. Bu afların sonuncusu, 18 Mayıs 2018 tarihinde Resmî Gazete'de yayımlanarak yürürlüğe girmiş olan, 7I43 sayılı Vergi ve Diğer Bazı Alacakların Yeniden Yapılandıııması ile Bazı Kanunlarda Değişiklik Yapılmasına Iliş̧kin Kanun'da 16. maddede yer alan ve İmar Kanunu'na geçici 16. madde ile dahil edilen "İmar Barış”"dır.

İmar Barışı ile 3। Aralık 2017 tarihinden önce kırsal ve kentsel alanlarda ruhsatsı veya ruhsat eklerine aykırı olarak yapılmıs tüm yapılar kanun kapsamına alınmış; 2960 sayılı Boğaziçi Kanunu'nda tanımlanan Boğaziçi sahil şeridi ve öngörünüm bölgesi, İstanbul Tarihî Yarımada içinde Süleymaniye ve Sultanahmet'in merkezde olduğu bölge, Çanakkale Savaşları Gelibolu Tarihi Alan, üçüncü kişilere ait özel mülkiyete konu taşınmazlar, kesinleşmiş planlar neticesinde sosyal donatı alanı olarak belirlenmiş ve Maliye Bakanlığınca aynı amaçla değerlendirilmek üzere ilgili kurumlara tahsis edilmiş Hazine'ye ait taşınmazlar bu kapsamın dışında tutulmuştur (Çevre ve Şehircilik Bakanlığı, 2018). Tarihi Yarımada özelinde kanun kapsamının dışında tutulan alanın nasıl, neden ve hangi ölçütlere göre belirlendiği konusu çeşitli platformlarda tartışıldıysa da tatmin edici herhangi bir cevaba ulaşılamamış, bir sonuca varılamamıştır. Tarihi Yarımada'nın korunması amacıyla uzun yıllardır kamu kurumları, üniversiteler, sivil toplum kuruluşları ve vatandaşlar tarafından gösterilen çabalara zıtlık arz eden ve UNESCO'nun Dünya Mirası Listesi'ne aldığı Tarihi Yarımada alanlarıyla da örtüşmeyen istisna sınırları üzerinde detaylı bir şekilde tartışılması gerekmektedir.

Kentlerin tarihî bölgelerinin ve bu bölgelerdeki kültürel miras ve kentsel dokunun korunması konusunda son yıllarda evrensel ölçekte büyük gelişmeler kaydedilmiştir. Türkiye de bu gelişmelere kayıtsız kalmamış ve birçok konuda atılım yaparak sürece ayak uydurmaya çalışış̧ır. Ancak kentlerin sorunlarını çözmek amacıyla uygulanan politikalar, kültürel mirasın ve 
kentsel dokunun zarar görmesine, bazen de tamamen kaybına neden olmuştur. Kentlerin, özelde de İstanbul ve Tarihi Yarımada'nın, sahip oldukları tüm değerlerin korunması suretiyle yaşatılabilmesi, planlı, programlı, hassas, titiz ve bütüncül bir yaklaşımla mümkündür.

İlhan Tekeli, planlama olgusunu koruma olgusuyla birlikte değerlendirmesi ve bu ilişkiye dair yaptığı çalışmalarla korumanın planlamadan ayrı düşünülemeyeceği savını güçlendirmiş bir akademisyendir. Uzmanlık alanının kent ve bölge planlama olduğunu belirten İlhan Tekeli'nin kentsel korumaya dair fikirleri kentsel korumanın öneminin farkına varılması ve ilkelerinin benimsenmesi noktasında büyük önem taşımaktadır. Kültürel ve tarihsel değerlerin korunması konusundaki hassasiyet ve farkındalığının öğrencilik yıllarında modernitenin yıkıcı yüzüyle karşılaşmasına bağı olarak geliştiğini ifade eden Tekeli, 1960'lı yıllara gelinirken dönemin başbakanı Adnan Menderes'in adeta bir İstanbul Belediye Başkanı gibi hareket ederek imar operasyonlarına giriştiğini ve birçok tarihî binanın yıkıldığını belirtmiş, kültürel ve tarihsel değerlerin korunması ve sürdürülmesinin doğrudan uzmanlık alanı olmamasına karşın, bu konuların kendi uzmanlık alanıyla yakın ilişkili olduğunu, bu konularla ilgilenmeyi ve bir tutum sahibi olmayı bir vatandaşlık görevi olarak gördüğünü söylemiştir (Tekeli, 2009a, s. I-2). Bu nedenle çalışmada Tekeli ve Keleş'in öncü fikirlerinin ağırlık teşkil etmesi konusunda hassasiyet gösterilmiş, planlama ve koruma ilişkisi konusunda kendisiyle örtüşen fikirlere sahip kişilerin görüşleriyle de söz konusu iki kavram arasındaki güçlü bağ vurgulanmaya çalışılmıştır.

Çalışmanın ilk bölümünde, Türkiye'deki planlama anlayışının yapısı ve dinamikleri temele alınmış, imar aflarını gündeme getiren kontrol ve plan dışı durumlar, bunların kentler üzerindeki olumsuz etkileri vurgulanarak irdelenmiştir. Bunun sonrasında, İmar Barışı düzenlemesi genel hatlarıyla ele alınmıştır. Devamında, İmar Barışı'nın planlama ve kentsel koruma olgularıyla ilişkisi derinlemesine masaya yatırılmıştır. Çalışmanın odak noktası olan bölümde ise İmar Barışı kapsamının dışında tutulan alanın nasıl belirlendiğine odaklanılmış, Sultanahmet ve Süleymaniye'den oluşan sınırların yarattığı çelişkiler, Tarihî Yarımada'nın kimliği, kentsel ve mimari dokusu ve kültürel mirası merkeze alınarak ortaya koyulmuştur. Ayrıca Tarihî Yarımada'da yürütülen saha araştırmasında kaçak ekler barındıran ve bölge için risk teşkil eden bazı yapıların güncel durumları söz konusu bölgede çekilen fotoğraflarla görünür kılınmıştır. Sonuç bölümünde ise araştırma kapsamında tespit edilen sorunlar özetlenmiş ve bu sorunların çözümünün sağlanması sürecinde göz önünde bulundurulması gerektiği düşünülen ilke ve gereklilikler sunulmuştur.

\section{2. İmar Aflarını Oluşturan Süreç}

Türkiye'de 1950'lerden itibaren hızlanmış olan kentleşme süreci özellikle büyük kentlerde bir nüfus yığılması yaratmıştır. Kontrol edilemeyen ve denetlenemeyen bu yığılma neticesinde insanlar barınma sorunlarını kendileri çözmek durumunda kalmıştır. Kentlerdeki bu yoğunlaşma ve genişleme karşısında birçok düzenleme yapılmış ise de uzun yıllara yayılmış olan bu sürece bakıldığında konunun bir anlamda akışına bırakıldığı söylenebilir.

Planlamalar, planların kanun dışı uygulamalarla bozulması, bu uygulamaların affı ve yeniden planlama yapılması şeklinde süregiden bu durum, günümüzde de benzer bir gelişme çizgisiyle ilerlemektedir. Tekeli, bu tekrar eden süreçle ilgili olarak, devresel bir planlama biçiminin ve buna bağlı olarak imar operasyonlarının beş nedene bağlanabileceğini dile getirmiştir. Bunların birincisi, kentsel altyapıların geliştirilmesi konusunda yönetimlerin düzenli ve yeterli bir mali kaynak akışına sahip olmamasıdır. İkincisi ise hızlı kentleşmeyi denetim altına alabilecek nitelik ve genişlikte bir planlama örgütünün kurulup sürekliliğinin sağlanamamış olması, yani yönetimsel kapasitenin sınırılığıdır. Üçüncü neden, ülkenin sermaye birikim şeklinde kentsel rantın önemli payı olması ve bu rantların dağılımında popülist bir siyasal politikanın izlenmesidir. Toplumun gözünde, bireylerin haklarına saygılı olmayan ve plansız uygulamaların yaşanan darboğazlar nedeniyle haklı görülmesi, daha genel ifadeyle ise toplumun siyaset kültürü, nedenlerin dördüncüsünü teşkil etmektedir. Beşinci neden ise planlamanın meşruiyetinin dayanması gereken temelin, planlamanın rasyonalizmi olduğu kabulünün bir türlü aşındırılamamasıdır. Tüm bu nedenler de genel olarak hızlı kentleşme ve geri kalmış ülkelerin koşullarıyla ilişkilidir (Tekeli, 20I3, s. 360-36I). Keleş ise kent planlarını uygulamanın, bireysel yararlarla kamu yararının çatıştığı durumlarda ve toprakta özel mülkiyetin mutlak ve kutsal olduğu devlet anlayışında kolay olmadığına dikkat çekmiştir. Buna bağlı olarak da planlar sık sık değişikliklerle yozlaştırılmakta, bireysel çıkarların korunması amacıyla kent içi bölge ve kat kurallarında benzer sıklıkta düzenlemeler yapılmaktadır. İmar afları da bu noktada, bireyleri plana uymaya zorlayamayan yönetimlerin, kaçak yapı yapma eylemi olan imar oldubittilerini bağışlayıp yasallaştırma işlemleri olarak ortaya çıkmaktadır (Keleş, 2019, s. 2I5).

Tekeli'ye (2009b, s.272) göre sadece piyasa mekanizmasının inisiyatifine bırakılamayacak olan ve kendine özgü nitelikleri dolayısıyla bir düzenleme rejimi gerektiren kentsel gelişme, plan dışı izinsiz gelişmeler ve bunların meşrulaştırılması sürecini içermektedir ve planlamanın güçlü bir şekilde kurumsallaşmadı̆̆ı, yerel yönetimlerin yeteri kadar güçlü olmadığı bir ortamda plan dışı izinsiz gelişmelerin kaynaklandığı çeşitli etkenler vardır. İlki, güçlü merkezî yönetimin, binalarını yerel yönetimin iznini göz önünde bulundurmaksızın yapmayı gücünün bir işareti olarak görmesi, bir diğer deyişle bizzat hükümetin kurallara uymamasıdır. İkinci etken, yürürlükte olan imar kuralları ve planlama anlayışının toplumun düşük gelirli ve yeni kentleşen kesiminin gerçekleriyle örtüşmemesidir. Bu kesim, kentteki varlığını yalnızca izinsiz ve kural dışı yapılar yaparak güvence altına alabilmekte olup bu yapıların sayısı da belli bir büyüklüğe ulaştığında büyük 
bir yatırım miktarına tekabül etmektedirler. Ulusal servetin ziyan edilmemesi gerekçesiyle de bu yapılar yeni düzenlemeler ile meşrulaştırılmaktadırlar. Üçüncü etken ise afların tekrarlayan bir seyir izlemesi, bir diğer deyişle düzenlenen bir kurum hâline gelmesidir. Buna bağlı olarak da o zamana kadar imar kurallarına uyan toplum kesimleri ve kent bölgelerinde izin yapıların yaygınlaşması sonucu doğmaktadır (Tekeli, 20I3, s. 340).

Tekeli, kanun dışı yapılaşma ile ilgili gözlenen sorunların bir bölümünün, planlamanın kontrol talebinin kentlerdeki mülkiyet düzeniyle tutarlı olmamasından kaynaklandığını, kentlerde çok yaygın bir özel mülkiyet olgusunun söz konusu olduğunu ifade etmektedir. Bu durum da mülk sahiplerinin planda kendilerine tanınan imar haklarını aşma ve bu yolla kentin genişlemesi sırasında kendi arsaları üzerinde oluşacak imar rantlarına el koyma çabasını yaratmakta, devamında da yapılan planın bozulması ve uygulanmaması için baskı kurmaları söz konusu olmaktadır (Tekeli, 2009b, s.303). Keleş de aynı noktaya temas etmekte, kent topraklarındaki özel mülkiyet ilişkileri nedeniyle, kent planları vasıtasıyla kentsel gelişmeye yön vermek olanağı bulunamadığını ifade etmektedir. Bireyler, rant odaklı yaklaşımları nedeniyle planları yozlaştırmakta, buna ek olarak da merkezî ve yerel yönetimlerin bu rant arayışlarına seyirci kalmaları durumu söz konusu olmaktadır (Keleş, 2019, s.219). Tekeli'nin bağlayıcı cümleleri de tüm bu tekrar eden süreci özetler niteliktedir. Tekeli'ye göre gecekondu aflarıyla başlayan imar afları, kentsel toprak mülkiyeti düzeni ve imar düzeninin iflasıdır. Tekeli, imar planlarının kamu yararını gerçekleştirdiği kabul edildiğinde, ona aykırı olan bir taşınmazın da toplumun düzenini bozacağının ve kişileri rahatsız edeceğinin de kabul edilmesi gerektiğini ifade etmiş, affedilen taşınmazların ömürlerinin uzunluğu sebebiyle kazanılmış hak hâline geleceklerini ve böylelikle bu taşınmazların affının da bir anlamda toplumun cezalandırması anlamını taşıyacağına dikkat çekerek imar aflarının kendi içindeki çelişkisini vurgulamıştır (Tekeli, 2009c, s.86-87). Çavuşoğlu da imar afları sonucunda estetik, teknik ve altyapı açısından son derece yetersiz kentsel alanlar ortaya çıkabildiğini, bu sağlıksız yapı stokunun her doğal afette can ve mal kayıpları yaratabildiğini, bunun da çok maliyetli bir kentleşme modeli olduğunu ifade etmiştir. Bu modelde kent topraklarının yağmalandığını, afların bir süre sonra yasal bir yaşam süren kesimlere yönelik bir cezalandırma, kanun dışı faaliyetler için ise bir ödüllendirme hâline geldiğini vurgulamıştır (Çavuşoğlu, 2016, s.190).

Keleş'in, imar planları vasıtasıyla kent ve kentleşme sorunlarını çözmekte karşılaşılan asıl sorunun insan davranışları olduğu yönündeki tespiti, İmar Barışı'nın ortaya çıkmasını sağlayan etkenin insanların kanun dışı uygulamaları olduğu düşünüldüğünde tutarlılık arz etmektedir. Keleş'e göre insanlar, plan kararlarına uymakta kent ve toplum adına özverili davranmak yerine kısa erimli ve bencilce bir tutum sergilemektedirler. Kent toprağındaki ranttan pay koparabilmek söz konusu olduğunda insanlar, yaş, cinsiyet, eğitim ve kültür düzeyi fark etmeksizin kent, imar, planlama, çevre gibi değerleri koruma konusunda duyarsız bir tavır takınmaktadırlar. Keleş, bu noktada, çağdaş bir toplumda bireylerden beklenenin, imar planları gibi sınırlamalar karşısında bireysel çıkarlar ve kamu çıkarları arasında bir denge kurmaları ve bu anlayış ışığında özverili davranmaları, yurttaşılı görev ve bilincine uygun hareket etmeleri olduğunu ifade etmiştir (Keleş, 2019, s.220-22I). Tekeli de benzer bir tespitte bulunmuş, insanların kendi mülkleri söz konusu olmadığı zaman düşük yoğunluklu ve bol yeşilli bir yaşam çevresi istediklerini, tarihî çevre ile doğal çevrenin korunmasının gerektiğini kabul ettiklerini ve bunları tahrip edenleri eleştirdiklerini, ancak kendi mülkleri söz konusu olduğunda bu değer ve hassasiyetleri unuttuklarını belirtmiştir. Mülk kişinin kendine ait ise yasal çerçeveyi aşmanın yollarının arandığını, çevrenin kirletildiğini, bazen işin siyasilere baskı yapmaya ve rüşvet girişimlerine kadar vardığını, tüm bunların da sessiz bir şekilde gerçekleştiğini söyleyen Tekeli'ye göre bu süreç toplumda hâkim hâle gelmiş ve belirleyici olmuştur (Tekeli, 2009a, s.83; 2009c, s.80).

Kentteki insan kaynaklı tahribat konusunda Keleş, "kent suçu” ve "kente karşı suç" kavramlarına dikkat çekmiş ve bu kavramları, kentin kent olma nedeniyle sahip olduğu kimi özelliklerinin ve değerlerinin yok edilmesine yönelik eylemler olarak tanımlamıştır. Bu bağlamda kent suçu olarak addedilebilecek birçok eylem sıralayarak bunlar sonucunda kentlerin yalnızca fiziksel olarak zarar görmediğini, kent kimliğinin ve kentlilik haklarının da zarardan paylarını aldıklarını belirtmiş, bu suçların önemli bölümünün de imar kararları ve uygulamaları sonucunda ortaya çıktığını söylemiştir (Keleş, 2019, s. 132).

Tekeli, kentte yaratılan tahribatın nedenlerini irdelerken, konuya zamanda gerilere giderek genel bir çerçeveden de yaklaşmış, kapitalizmin ve modernitenin çok güçlü yıkıcılık mekanizmaları bulunduğuna vurgu yapmıştır. Tekeli, Schumpeter'ın öne sürüp geliştirdiği bir olgu olan 'kapitalizmin yaratıcı yıkıcılığı'nın ve modernite projesinin evrensellik iddialarının, tarihsel olanın korunması yerine yıkılması eğilimi gösterdiğini ve bu yıkıcılığın kapitalizmin kısa erimli mantığının bir sonucu olduğunu belirtmiştir. Buna bağıı olarak da toplumda tarihî sürekliliğin yok olması ve köksüzleşme gibi sorunlar baş göstermektedir (Tekeli, 2009a, s. 105). Bu tespit, birçok semtte kentsel dönüşüm için aciliyet arz etmeyen, ancak mülk sahiplerinin daire ve yatırımlarının değer kazanması amacıyla binalarını yenilemeleri örneğiyle doğrulanabilmektedir. İstanbul'un Kadıköy ilçesindeki Feneryolu, Göztepe, Erenköy, Suadiye gibi yerleşimlerdeki birçok yapı bu nedenle yenilenmiştir. Kentteki dönüşüm sürecinin, yapı güvenliği açısından aciliyet arz eden muhitler yerine aciliyet sırasında gerilerde gelen muhitlerde gerçekleşmesi, kapitalizmin kısa erimli mantığının yansımaları olarak görülebilir. Tekeli, konuyu aynı perspektiften değerlendirmeyi sürdürerek modernitenin yanına mülkiyet kavramını eklemiş, modernist toplumda bir insanın, mülkiyet hakkını kullanarak, korunması gereken kültürel değeri yüksek bir bina yerine yeni ve getirisi daha yüksek bir 
bina yapmasının toplumsal bir sonucu olduğunu, binanın, varlığı ve görünüşüyle diğer insanların günlük yaşamının parçası olduğunu ve o çevrenin kimliğini etkilediğini belirtmiştir. Kimliği olan ve tarihin sürekliliğinin yok edilmediği bir yerde yaşamanın o toplumda yaşayan bireylerin onurlu yaşam hakkının bir parçası olmasından hareketle de kültürel değeri olan bir binaya zarar veren mülk sahibinin kendi mülkiyet hakkını kullanırken çok sayıda insanın onurlu yaşam hakkına zarar verdiği tespitinde bulunmuştur (Tekeli, 2009a, s. I I I). Tekeli, bu noktada, liberalizmin mülkiyet anlayışını hatırlatarak bu anlayışın, bir toprağın ya da bir taşınmazın sahibi olan kişiye mutlak bir hâkimiyet sağladığını, kişinin isterse toprak üstündeki yapıyı yıkabileceğini, satabileceğini ya da boş bırakabileceğini belirtmiş, taşınmazlar üzerindeki bu mülkiyet anlayışının, kişinin kent mekânında yapacağı yıkımı kendisi için kârlı hâle getirebildiğine dikkat çekmiştir (Tekeli, 2009a, s. 109).

\section{3. İmar Barışı}

Çevre ve Şehircilik Bakanlığı tarafından bakanlığın resmî internet sitesinde paylaşılan tanıtım broşüründe "İmar mevzuatına veya ruhsata aykırı yapılara verilecek yapı kayıt belgesiyle vatandaşlarımızın imar sorunlarının çözülmesidir" şeklinde tanımlanmış olan İmar Barışı'nda bakanlık nezdinde hükümetin hedefi "Vatandaşlarımızın devletle ihtilaflı durumunu ortadan kaldırmak, imara aykırı, ruhsatsız veya ruhsat eklerine aykırı olan yapıların kayıt altına alınması yoluyla bu yapılara yasalık kazandırmak" olarak açıklanmıştır (Çevre ve Şehircilik Bakanlığı, 20।8). Aynı belgede Türkiye'deki imara aykırı yapıların toplam yapı sayısına oranının \%50'lere ulaştığı ve bunun da 13 milyon gibi bir sayıya tekabül etmesi, bu yüksek oran nedeniyle de vatandaş ve belediyeler arasında imar kaynaklı sorunlardan ötürü ortaya çıkan sorunların mahkemelerde altından kalkılamayacak bir yoğunluğa ulaşması, belediyelerin imara aykırı yapıların yıkılması konusunda aksaklıklar yaşamaları, vatandaşın elektrik, su, doğal gaz kullanımlarından mahrum kalmaları ya da bunları kaçak kullanmak zorunda kalmaları gibi sorunlar neticesinde bu düzenlemenin yapıldığı ifade edilmiştir.

Kanun, 18.05.2018 tarihinde, 30425 sayılı Resmi Gazete'de yayımlanmak suretiyle yürürlüğe girmiştir. 7|43 sayılı Vergi ve Diğer Bazı Alacakların Yeniden Yapılandırılması ile Bazı Kanunlarda Değişiklik Yapılmasına İlişkin Kanun'un 16. maddesinde, 3194 sayılı İmar Kanunu'na Geçici Madde I6'nın eklendiği ifade edilmiştir. Bu maddeye göre, afet risklerine hazırlık kapsamında ruhsatsız veya ruhsat ve eklerine aykırı yapıların kayıt altına alınması ve imar barışının sağlanması amacıyla, 3I.12.20।7 tarihinden önce yapılmış yapılar için Çevre ve Şehircilik Bakanlığı ve yetkilendireceği kurum ve kuruluşlara 31.10.2018 tarihine kadar başvurulması, bu maddedeki şartların yerine getirilmesi ve 3I.I2.20I8 tarihine kadar kayıt bedelinin ödenmesi halinde Yapı Kayıt Belgesi verilmesi planlanmıştır. Yapı Kayıt Belgesi ile a) 2960 sayılı Boğaziçi Kanunu'nda tanımlanan Boğaziçi sahil şeridi ve öngörünüm bölgesi, b) İstanbul Tarihi Yarımada için- de Süleymaniye ve Sultanahmet'in merkezde olduğu bölge, c) Çanakkale Savaşları Gelibolu Tarihi Alan, ç) üçüncü kişilere ait özel mülkiyete konu taşınmazlar, d) kesinleşmiş planlar neticesinde sosyal donatı alanı olarak belirlenmiş ve Maliye Bakanlığınca aynı amaçla değerlendirilmek üzere ilgili kurumlara tahsis edilmiş Hazine'ye ait taşınmazlar haricindeki ruhsatsız veya ruhsat eklerine aykırı bütün yapıların yasal hâle getirilmesi söz konusu olmuştur.

\section{4. İmar Barışı, Planlama, Kentsel Koruma Iliş̧kisi}

Türkiye'deki imara aykırı yapı sayısının yüksekliğine ilişkin hükümet tarafından sunulan veriler, İmar Barışının ülkedeki kentlerin neredeyse tamamını doğrudan etkileyecek bir kapsama sahip oluşunun en önemli göstergesi olarak kabul edilebilir. Bu etkiler çok yönlü olup pek çok şekilde gözlemlenebilir durumdadır. İmara aykırı çok sayıda yapının yasal hâle getirilmesi, ekonomi, hukuk, sürdürülebilirlik, sosyoloji, çevre, planlama, afetler, koruma başta olmak üzere birçok açıdan önemli etkiler yaratmıştır. Makalenin odaklandığı nokta olan kentsel koruma, İmar Barışı'nın yarattığı sonuçlardan doğrudan etkilenecek olan kentlerin tarihî ve kültürel mirasının yaşatılmasına odaklanan bir kavram olduğundan bu bölümde kentlerdeki tahribatın sebepleri irdelenmiş, planlamanın önemine vurgu yapılmış, kentlerin kimliklerinin ve kentsel koruma kavramının önemine değinilmiş ve bu hususların İmar Barışı ile ilişkisi incelenmiştir.

\section{I. Planlamanın Gerekliliği ve İmar Affı Döngüsü}

Arsa sahibinin yarattı̆̆ı dışsallığın maddi ve manevi pahasını tüm kentin ödediği bir ortamda Tekeli'ye göre bu kullanım özgürlüğünün sınırlanması gerekmektedir ve bu sınırlama da devlet tarafından yapılan idari bir işlem niteliğindeki imar planı ile getirilmektedir. Kamu yararını sağlamak ve kente bir düzen getirmeyi amaçlayan planlar ile arsa sahiplerine, bazı haklar verilmesinin yanında toplumun ve komşularının çıkarının sağlanması açısından bazı görevler de yüklenmiş, mülkiyet hakları bir anlamda sınırlanmıştır (Tekeli, 2009c, s.75). Tekeli, kentin planlamasını modernitenin bir diğer yüzü olarak öne çıkarmış, kent taşınmazları üzerinde kuvvetli bir mülkiyet hakkı olmasının kapitalizm açısından bir felaket senaryosu ortaya çıkaracağını belirtmiştir. Buna göre işleyiş, kentin yapılanması üzerinde hiçbir denetim kurulmadan serbest piyasa mekanizmasına bırakılsaydı, birbirinin yatırımını değersizleştiren uygulamalar söz konusu olurdu. Kent planlaması da işte bu felaket senaryosunun gerçekleşmesini önlemek için kurumsallaşmış olup yeşil alanları, yol sistemlerini, imar haklarını belirlemekte, bu yolla piyasa mekanizmasının kapitalist girişimcilerinin birbirlerinin yatırımlarını değersizleştirmesinin önüne geçebilmektedir. Ancak Tekeli, çoğunlukla bu akışın dışına çıkıldığını ve mekanizmanın yıkıp yapmayı hızlandıracak şekilde dönüştüğünü, böylelikle kapitalist sistemin ve mülkiyet anlayışının kentlerin tarihsel dokuları üzerinde dönüşüm baskısı yarattığını da eklemektedir (Tekeli, 2009a, s. I I0). 
Tekeli'ye göre "aydınlanma"nın çocuğu olan planlama (Tekeli, 2009b, s.2), temelde kaderine razı olmaya bir karşı çıkıştır (Tekeli, 2010, s.212) ve kamu yararına olmak, bilimsellik, disiplinlerarası olma, yaratıcılık şeklinde dört temel değeri bulunmaktadır (Tekeli, 2009b, s. 15). Ancak yukarıda da değinilmiş sebepler neticesinde sık sık plan dışı kalınması, plan dışı yollar üretilmesi söz konusu olmakta (Tekeli, 2009c, s.77), bunun da sonrasında yeni planlar yapıldığında ise eskiden yapılmış uygulamaların kazanılmış hak olarak kabul edildiği durumlar cereyan edebilmektedir (Tekeli, 2009c, s.84).

Keleş, imar planlarının, dar anlamda, kent toprağının içinde bulunan zaman ve gelecekteki kullanım biçimini belirleyen bir resmi belge olarak algılandığını, oysa imar planlarının yalnızca kentsel toprağın kullanım biçimini belirlemediğini, yaşam kalitesinin yükseltilmesi; konut, ulaşım ve diğer kamu hizmetlerinin karşılanması; ekolojik, kültürel ve tarihsel değerlerin korunması gibi amaçlarının da söz konusu olduğunu ve geniş anlamda kavranması gerektiğini dile getirmiş̧ir (Keleş, 2019, s.2I2).

Tüm bu gelişme ve aksaklıklar neticesinde ortaya çıkan imar operasyonları Tekeli'ye göre temelde siyasal bir etkinliktir ve kentte toplumun hemen hemen her kesiminin etkilendiği ve mevcut dinamiklerle aşılamayan bir darboğaz gelişince bu durumun olası çözümünün siyasi getiri potansiyelinin artması söz konusudur (Tekeli, 2013, s.340). İmar afları, böyle darboğaz dönemlerinde, plan dışı gelişmelerin planlı gelişmeleri aşması ve bu gerçekliğin yönetimlerce kabul edilmesiyle var olmuştur (Tekeli, 2010, s.218). Keleş'e göre imar affı olgusu, imar suçlarını işlemiş olan kişilerin, kendilerinden belli bir miktarda para cezası alarak veya almayarak bağışlanmaları olayıdır (Keleş, 2019, s.393). Ancak gelinen noktada bu bağışlanma bir şekilde tekrarlayan bir sürece girmiş olup imara aykırı yeni uygulamaların yolunu açmakta ve kişileri her seferinde yeni afların çıkacağı düşüncesine sevk edip cesaretlendirmektedir. Nitekim geçmişten günümüze baktığımızda imar afları tekrarlayan bir seyir izlemekte ve bazı şekil değişiklikleriyle yeniden yürürlüğe koyulmakta, bir döngü hâlini almaktadır.

\subsection{Kentsel Koruma}

Kent imajını etkileyen; her kentte farklı ölçek ve yorumlarla kendine özgü nitelikler taşıyan; fiziksel, kültürel, sosyo-ekonomik, tarihsel ve biçimsel faktörlerle şekillenen; kentler ve onların yaşam biçiminin oluşturduğu; sürekli gelişen ve sürdürülebilir kent kavramını yaşatan; geçmişten geleceğe uzanan büyük bir sürecin ortaya çıkarttığı anlam yüklü bütünlük olarak tanımlanan (Çöl, 1998, s. I4) kent kimliği Tekeli'ye göre tarihsel bir olgu olup zaman içinde oluşur ve değişebilir. Buna bağılı olarak da uzun bir tarihsel geçmişi olan kentlerin, zamanın değişik katmanlarının üst üste birikmesiyle oluşmuş bir kimliği olduğu söylenebilir. Kent kimliğinin önemli bir yanı da toplum tarafından üretiliyor oluşudur. Bir kişi, kentin her yerini tek başına algı- layamamakta, başka bir deyişle kent parça parça algılanabilmektedir. Her bir kişinin algıladığı mozaik parçalarının birleşmesiyle bir kent imgesi oluşmakta, çok sayıda kişinin katkısıyla uzun bir süreçte yaratılan bu imge yine bizzat toplumun deneyimleri ve değişen algısı vasıtasıyla zaman içinde değişime uğrayabilmektedir (Tekeli, 1990, s.253-255). Gelinen noktada ise ekonomik sebeplerin, kentte yaşayan insanların duyarsızlığının, yerel yönetimlerin yaşadığı krizlerin kentlerimizi şekillendirmekte, tek tipleştirmekte olduğu görülmektedir. Bu da bir anlamda patates baskısı olarak nitelenebilecek, dokusunu kaybetmiş, kimliğini arayan kentlerin oluşmasına sebep olmuştur (Beyazıt, Gül ve Güneş, 2013, s. 159). Öyle ki günümüzde yok olma sürecine girmiş olan kent kimliklerinin ve belleklerinin korunması ile tarihî kentsel dokuların canlandırılması, sosyal, ekonomik ve fiziki mekânların birlikte bütüncül olarak ele alınması ve planlanması gerekliliği, çağdaş koruma anlayışının da çerçevesini çizmiştir (Türkiye'de Tarihi Kent Dokularının Korunması ve Geleceğe Taşınması Sempozyumu I. Komisyon Sonuç Raporu, 2002, s. I34). Kent kimliklerinin, bu kimlikleri oluşturan kentsel dokuların, kültürel ve mimari mirasın korunması konusunda öne çıkan ve koruma literatüründe sıklıkla atıf yapılan 1975 tarihli Amsterdam Bildirgesi de bu bağlamda önemlidir. Bildirgenin temelinde yer alan "bütünleşik koruma", kentlerin kimliğini oluşturan mimari dokunun korunması açısından çerçeve niteliğinde ve yol gösterici mahiyette bir yere sahiptir. İstanbul Tarihî Yarımada da 1950'ler sonrasındaki apartmanlaşma sürecine karşın birçok açıdan tarihsel, mimari ve kültürel kimliğini korumakta, ancak bunun sürdürülebilirliğinin sağlanması için ise uluslararası koruma sözleşmeleri ışı̆̆ında özen görmesi gerekmektedir.

Koruma kavramı, zaman ve mekânın zihinsel tahayyülde ayrışması nedeniyle ortaya çıkmış modern bir sorundur (Özaslan, 20।0, s. 10). 2863 sayılı Kültür ve Tabiat Varlıklarını Koruma Kanunu'nun 3. maddesinde koruma "taşınmaz kültür ve tabiat varlıklarında muhafaza, bakım, onarım, restorasyon, fonksiyon değiştirme işlemleri" olarak tanımlanmıştır. Hasol'a göre ise koruma, tarih veya sanat değeri taşıyan yapıların, doğal değerlerin ya da kent parçalarının yaşamlarını sürdürebilmeleri için muhafaza, onarım ve bakıma ilişkin önlemleri almaktır (Hasol, 20I2, s.279).

Tarihî yapı ve alanların korunması ile kentsel koruma ise farklı biçimlerde gelişen iki ayrı etkinlik alanıdır. Tarihî öneme sahip yapı ve alanlarının korunmasının yüzyıllara dayanan bir geçmişi bulunmasına karşın kentsel koruma yeni sayllabilecek bir hedeftir. Tarihî kentsel alanlar; anıtsal yapılar ve özel tarihî değeri olan yapıların yanı sıra mütevazı ve sıradan pek çok yapıyı da barındırması nedeniyle, kentsel alanların korunmasına odaklanan kentsel koruma, tek tek yapıların korunmasından çok daha kapsamlı ve karmaşıktır (Doratlı, 2007, s. I3). 1964 tarihli Venedik Tüzüğü'nde bu konu açıkça vurgulanmıştır. Tüzükte, tarihî anıt kavramının yalnızca bir mimari eseri içine almadığı, bunun yanı sıra belli bir uygarlı̆ı̆n, önemli bir gelişmenin tarihî bir olayın 
tanıklığını yapan kentsel veya kırsal yerleşmeleri de kapsadığı görüşü önemlidir. Nitekim Ahunbay da anıtsallıktan uzak, tümüyle işlevsel amacı olan gündelik yaşama ait yapıların da uzun bir süre geçtikten sonra, toplumsal tarihe ait bir bileşen olarak değer kazanmakta ve koruma kapsamına alınmakta olduğunu vurgulamıştır (Ahunbay, 1999, s.22). Kentsel koruma, kent bilimleri sözlügünde, kentlerin belli kesimlerinde yer alan tarihsel ve mimari değerleri yüksek yapıların, anıtların ve doğal güzelliklerin kentte bugün yaşayanlar gibi gelecek kuşakların da yararlanması için rehabilite edilmesi ve her türlü yıkıcı eylem karşısında güvence altına alınması olarak tanımlanmaktadır (Çınar ve Kart, 2005, s.72). UNESCO da Tarihî Kentsel Peyzaja İlişkin Tavsiye Kararı'nda kentsel korumayı tek tek binaların korunmasıyla sınırlı görmemekte, mimariyi bütün kentsel yerleşimin bir unsuru olarak kabul etmektedir (UNESCO, 20 I I) ve bu şekilde kentsel koruma karmaşık ve çok yönlü bir disiplin olmaktadır. Böylelikle de tanımı itibarıyla kentsel koruma, kentsel planlamanın merkezine yerleşen bir kavram olarak ortaya çıkmaktadır.

Tekeli, insanlığın, kültürel mirasını korumaya yönelmiş olmasını onun varlık sorunuyla ilişkilendirmiş, insanın bir yerde ve bir zamanda var olmak istediğini, yaşamının anlamını da o yerle ve zamanla kurduğu ilişkide bulduğunu, koruma duygusunun da bunun üzerinden geliştiğini ifade etmiştir (Tekeli, 2009a, s.I0I). Bunun yanı sıra günümüzün küreselleşmiş dünyasında kültürel mirasın da ulusların kültürel mirası olmaktan çıkıp dünya mirası hâline geldiğini vurgulamış, uluslararası kurumların da bu mirasın korunması konusunda kararlar almakta ve ulusal kurumlara sorumluluklar yüklemekte olduğunu, ancak ülke içinde bir farkındalık yaratılmadığı ve tarih bilinci ile koruma bilinci geliştirilmediği müddetçe tüm çabaların sonuçsuz kalacağını öne sürmüştür (Tekeli, 2009a, s. I I3).

Kültürel mirasın korunması, ülkelerin sosyo-ekonomik göstergeleri veya güçlerine göre değişiklikler göstermektedir. Sanayide ilerlemiş ve yeterli birikimi sağlamış olan gelişmiş ülkeler koruma konusunda daha duyarlı ve başarılı bir seviyeye ulaşmış iken, kalkınma sürecine geç girmiş olan ülkemizde koruma bilincinin tartışılmaya açılması ve gelişmesi de aynı ölçüde geç gerçekleşmiştir (Özgünel, 2007, s.47). Ülkemizde koruma konusunda bir karmaşa söz konusudur. Yasal düzenlemeler, belli bir bütünlük ve sistematik içinde değil, dönemin gereksinimleri ve belli odakların çıkarları doğrultusunda yapılmış, bunun sonucunda kimi alanlarda yetki ve sorumluluklar iç içe geçmiş, kimi alanlarda da boşluklar oluşmuştur (Duru ve Turan, 20I3, s. I23). İstanbul özelinde son yıllarda bu karmaşa daha da belirginleşmiş, Haydarpaşa Garı, Galata Kulesi gibi İstanbul açısından simge yapılarda merkezî yönetim ve büyükşehir belediyesinin düşünce ve tasarrufları uyuşmamış, konu akademi ve ulusal medya düzleminde ciddi şekilde tartışılmıştır.

Tekeli'ye göre koruma politikaları, kapitalizmin kısa erimli mantığının işleyiş biçimini etkileyerek toplumun uzun erimli mantığıyla uyumlu hâle gelmesi için çalışmalıdır. Mülkiyet hakkının yıkıcı bir şekilde kullanılmasının toplum aleyhine olan sonuçları kısa sürede fark edilemeyecek olsa da sonuçlar birikmeye başladığında tarihsel olanın geri dönüşü olmayacak şekilde tahrip edildiği ortaya çıkmaya başlamakta ve bunun sonucunda da koruma politikaları oluşmaktadır (Tekeli, 2009a, s. I I I-I I2). Çubuk da benzer bir noktaya temas ederek kamu yararından birey yararına dönüş ve devlet merkezli gelişme stratejilerinden piyasa merkezli stratejilere geçişe vurgu yapmış, rant amaçlı plan değişikliklerinin kentlerde, tarihsel ve doğal çevrelerde geri dönüşü olmayan kayıplara yol açtığını dile getirmiştir (Çubuk, 20 I8, s.508).

Koruma anlamında ülkemizdeki süreci de etkileyen ve geliştiren uluslararası yasal ve yönetsel sürecin kilometre taşı niteliğinde gelişmeleri söz konusudur. Tarihî yapıların evrensel miras olduğu gerçeği 18. yy'dan itibaren kabul edilmiş olmasına karşın uluslararası geçerliliği olan ilkeler ve uygulamalar ancak 20. yy’da söz konusu olabilmiştir. Birinci Dünya Savaşı'nın yıkıcı etkilerinin önüne geçmek çabası, 193I yılında Atina Tüzüğü’nü, İkinci Dünya Savaşı'nın yarattı̆̆ı tahribatı azaltmak çabası ise önce UNESCO (Birleşmiş Milletler Eğitim, Bilim ve Kültür Organizasyonu), ardından ICOMOS (Uluslararası Anıtlar ve Sit Alanları Konseyi) gibi kuruluşların başını çektiği tedbirlerin alınmasını sağlamıştır. Bunlara bağlı olarak 1964 yılında Venedik Tüzüğü, 1972 yılında UNESCO Dünya Kültürel ve Doğal Mirasın Korunması Sözleşmesi, 1987'de Washington Deklarasyonu, 2005'te UNESCO Dünya Mirası Uygulama Rehberi gibi gelişmelerle uluslararası ölçekte bir birlik ve farkındalık sağlanmaya çalışılmıştır.

Ülkemizde ise Osmanlı döneminden günümüze dek birçok yasa çıkarılmıştır. Asar-ı Atika Nizamnameleri, Muhafaza-i Abidat Kanunu, Esvar ve Kala-i Atikadan Belediyelere Vilayete Terk Olunacak Yerler Hakkında Kanun, 195I tarihli ve 5805 sayılı Gayrimenkul Eski Eserler ve Anıtlar Yüksek Kurulu Teşkili ve Vazifelerine Dair Kanun, 1973 tarihli ve 1710 sayılı Eski Eserler Kanunu, 1983 tarihli ve 2863 sayılı Kültür ve Tabiat Varlıklarını Koruma Kanunu, 2004 tarihli ve 5226 sayılı Kültür ve Tabiat Varlıklarını Koruma Kanunu ile Çeşitli Kanunlarda Değişiklik Yapılması Hakkında Kanun gibi kanunlar ülkemizin koruma anlayışındaki aşamaları ve çizdiği yasal çerçeveyi ortaya koyan atılımlardır.

Yapılan girişim ve düzenlemeler, kentlerin kimliğinin korunması ve geleceğe aktarılabilmesi içindir. Tekeli de "iyi” bir kentin nitelikleri arasında, tarihî ve kültürel anlamı bulunan yapı, bölge ve yaşam pratiklerinin korunması ile yerleşim estetiğinin, sanat, mimari, kent tasarımı ve planlanması alanlarındaki geleneksel, yerel, modern ve diğer stillerdeki gelişmeleri dikkate alan ve bunlar arasında müzakere sonucu oluşmuş dengeyi gözeten bir yöntemle oluşması gibi nitelikleri de sayarak kentsel korumanın önemini vurgulamıştır (Tekeli, 2009b, s.340-34I). 


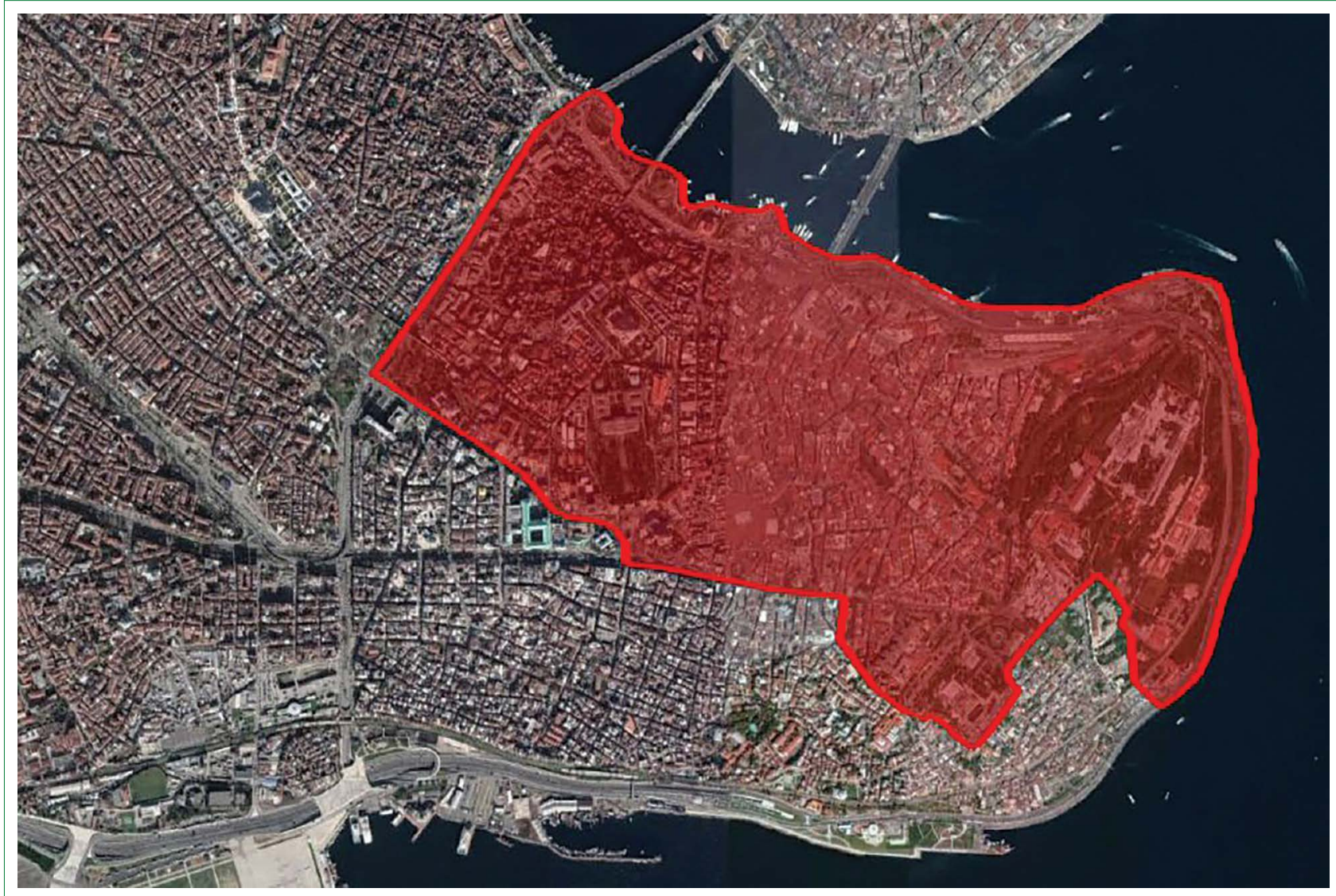

Şekil I. Tarihî Yarımada'da İmar Barısı kapsamının dışında bırakılan bölge [Kaynak: Çevre ve Şehircilik Bakanlığı (https: webdosya.csb.gov.trdbimar barisiiceriklertar-h-yarimada-2018060। 150242.pdf)].

\section{5. İmar Barışı'nın Tarihî Yarımada'daki Olumsuz Etkileri}

İmar Barışı düzenlemesi yapılırken bazı bölgeler bu düzenlemeden zarar görebilecekleri düşüncesiyle af kapsamının dışında bırakıımıştır. Tarihî Yarımada'nın, İmar Barışı düzenlemesi hazırlanırken bir istisnanın konusu yapılması, bu bölgenin düzenlemeyi hazırlayanlarca değerli ve özen gösterilmesi gereken bir yer olarak görüldüğünu göstermektedir. Ancak yasa kapsamına dahil olmayan bölgenin sınırları, bu sınırlar çizilirken birçok önemli konunun göz ardı edildiğini de açık biçimde ortaya koymaktadır. Tarihî Yarımada özelinde istisnaya konu olan bölge Çevre ve Şehircilik Bakanlı̆̆ı tarafından bir kroki ve koordinat listesi ile belirtilmiş olup, bu koordinatların birleştirilmesiyle oluşturdukları uydu görüntüsü görseli de paylaşılmıştır (Şekil I).

Tarihî Yarımada, imparatorluklara başkentlik yapmış, bir dönem dünyanın en kalabalık kenti olmuş, konumu ve önemi sebebiyle her daim birçok devlet ve topluluğun ilgisine mazhar olmuş, çeşitli uygarlıklar ve milletlerin kültürel, mimari ve tarihsel açıdan oluşturduğu katmanları barındırmış, dünya tarihi açısından önemli bir alandır. Bugün dahi birçok tarihsel, arke- olojik, tarihsel, mimari, sosyolojik araştırmaya konu edilmekte, henüz keşfedilmemiş gizemleriyle ilgi uyandırmaya devam etmektedir. UNESCO da Tarihî Yarımada'nın önemini gösterir nitelikte bir karar ile 1985 yılında dört alanı Dünya Mirası listesine dahil etmiştir. Yapılan İmar Barışı düzenlemesinde Tarihî Yarımada'nın bu özelliklerinin göz ardı edildiği, alanın, tarihsel ve kültürel bir birikimi olmayan yeni bir ilçe yaklaşımıyla ele alındığı görülmektedir.

Paylaşılan görseldeki sınırlara göre Tarihî Yarımada'nın bütününden oluşan Fatih ilçesindeki toplam 57 mahallenin 36 tanesi İmar Barışı'ndan faydalanabilmekte, 18 tanesi faydalanamamakta, 3 tanesinin ise bir kısmı faydalanabilmektedir. Faydalanabilen mahalleler, Aksaray, Akşemsettin, Ali Kuşçu, Atikali, Ayvansaray, Balabanağa, Balat, Cerrahpaşa, Cibali, Dervişali, Emin Sinan, Haseki Sultan, Hırka-i Şerif, İskenderpaşa, Karagümrük, Katip Kasım, Kemal Paşa, Kocamustafapaşa, Küçükayasofya, Mesihpaşa, Mevlanakapı, Mimar Hayrettin, Mimar Kemalettin, Molla Gürani, Muhsine Hatun, Nişanca, Saraç İshak, Seyyid Ömer, Silivrikapı, Sümbül Efendi, Şehremini, Şehsuvar Bey, Topkapı, Yavuz Sultan Selim, Yedikule, Zeyrek'tir. İmar Barışı'ndan faydalanamayacak mahalleler ise Alemdar, Beyazıt, Demirtaş, Hacı Kadın, Hobyar, Hoca Gıyasettin, Hocapaşa, 


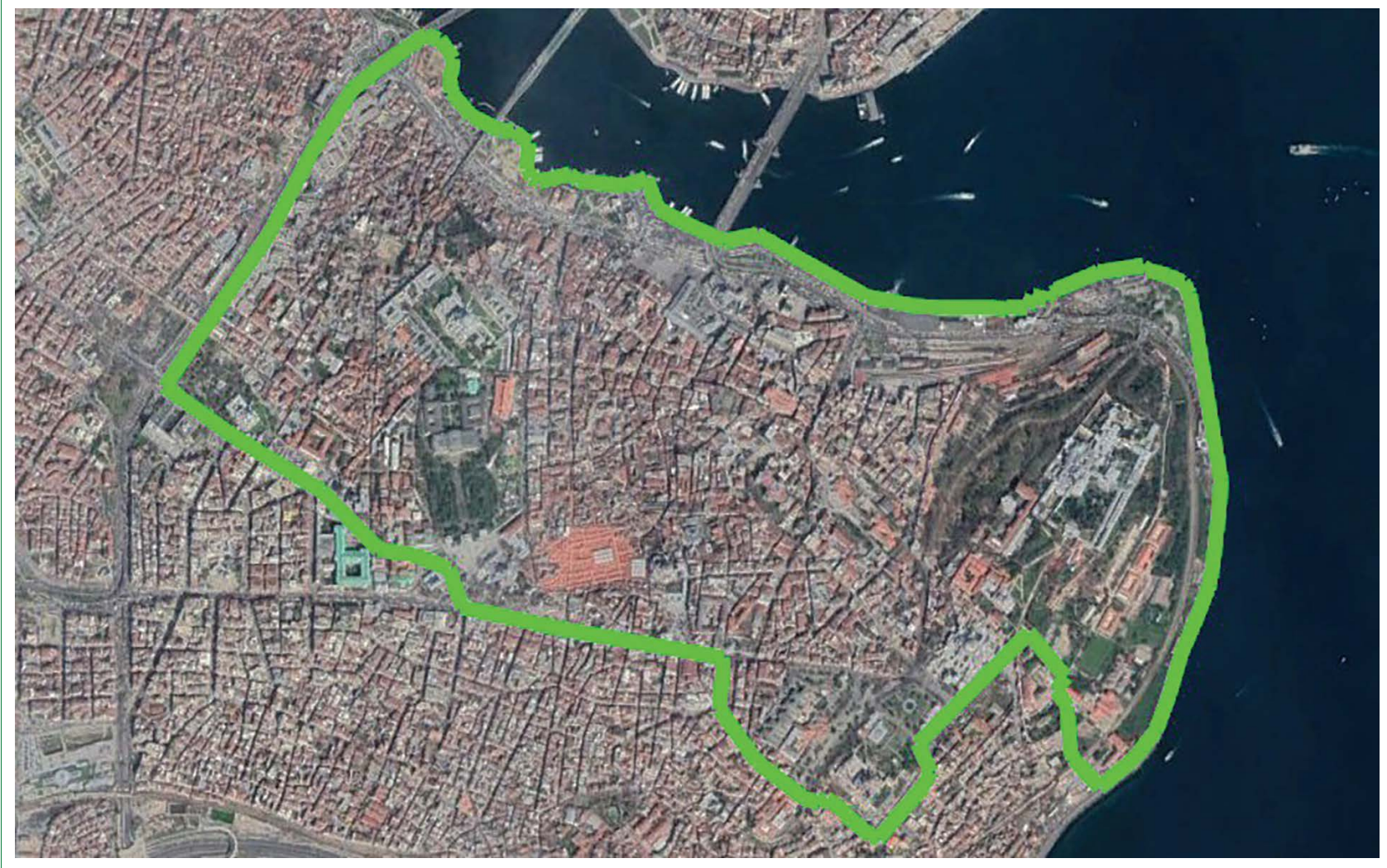

Şekil 2. Tarihî Yarımada'da İmar Barışı kapsamının dışında bırakılan bölgenin yazar tarafından Google Earth üzerinde gösterilmiş sınırları.

Kalenderhane, Mercan, Molla Fenari, Molla Hüsrev, Rüstempaşa, Sarıdemir, Sururi, Süleymaniye, Tahtakale, Taya Hatun, Yavuz Sinan'dır. Binbirdirek, Sultanahmet ve Cankurtaran mahalleleri ise sınırlara göre bölünmüş durumdadırlar.

İmar Barışı'nın Tarihî Yarımada istisnasının sınırlarını (Şekil 2) teşkil eden cadde ve sokaklar ise sırasıyla, Atatürk Bulvarı, Şehzadebaşı Caddesi, Vezneciler Caddesi, Darülfunun Caddesi, Yeniçeriler Caddesi, Boyacı Ahmet Sokak, Peykhane Caddesi, Üçler Sokak, Tavukhane Sokak, Torun Sokak, Dalbastı Sokak, Kabasakal Caddesi, Topkapı Sarayı sınırları içerisindeki isimsiz yol, Kennedy Caddesi, Reşadiye Caddesi ve Ragıp Gümüsspala Caddesi'nden oluşan bir hat izlemektedir.

Düzenlemede kapsam dışında bırakılan bölgede ön plana çıkan alanlar, İstanbul'un tarihî 7 tepesinin 3'ünü oluşturmaktadır: Sultanahmet, Nuruosmaniye, Süleymaniye. Sultanahmet Camii ve çevresi, Topkapı Sarayı, Kapalıçarşı ve Süleymaniye Külliyesi çevresinin sınırlar çizilirken ön plan da tutulduğu açıktır. Sınırlar dahilindeki bölge, yarımadanın diğer bölgelerine nazaran daha çok tarihî yapı barındırmaktadır. Ancak bu oran, diğer bölgelerdeki kültürel mirasın göz ardı edilmesine sebebiyet verecek ölçüde bir oran değildir. UNESCO, yukarıda da bahsedildiği gibi 1985'te Dünya Miras Alanları Listesi'ne İstanbul'un Tarihî Alanları'nı da eklemiş olup, bu alanlar Sulta- nahmet Kentsel Arkeolojik Koruma Alanı (gri bölge), Süleymaniye Camii ve Çevresi Koruma Alanı (sarı bölge), Zeyrek Camii ve Çevresi Koruma Alanı (kırmızı bölge) ve Kara Surları Koruma Alanı'ndan (mavi bölge) oluşmaktadır (Şekil 3).

İstanbul'un dünya tarihindeki yerini ortaya koyan önemli göstergelerden olan UNESCO Dünya Mirası Listesi, kentin sahip olduğu kültürel mirasın geleceğe aktarılmasında önemli payı olan bir takdirdir. Bu takdir, merkezi yönetim, yerel yönetimler, üniversiteler ve sivil toplum kuruluşlarının ortak çabası ile hayata geçirilen başvurular ile söz konusu olmaktadır. Üniversitelerin ilgili bölümleri ve sivil toplum kuruluşlarının araştırmaları ve projeleri merkezî yönetimin ilgili bakanlıkları nezdinde destek bulmakta ve dünya mirası olduğu düşünülen mekân ve alanlar için koruma uygulamaları hayata geçirilmektedir. Yerel yönetimlerin de bu miras alanlarının korunması konusunda yoğun çabası ve merkezî yönetim ile iş birlikleri söz konusudur. Bu çabalar neticesinde söz konusu mekân ve alanların dünya ölçeğinde tanınırlığı sağlanmakta, yasal çerçeveye alınmanın sağlanması ile birlikte koruma süreçleri hızlanmakta, ülkedeki kültür mirası konusundaki farkındalık artmakta, bu durumun turizme de büyük katkısı olmaktadır.

İmar Barışı'na dönüldüğünde ise UNESCO listesinde bulunan sadece iki alan için korunma çabası gösterilmiş olması 


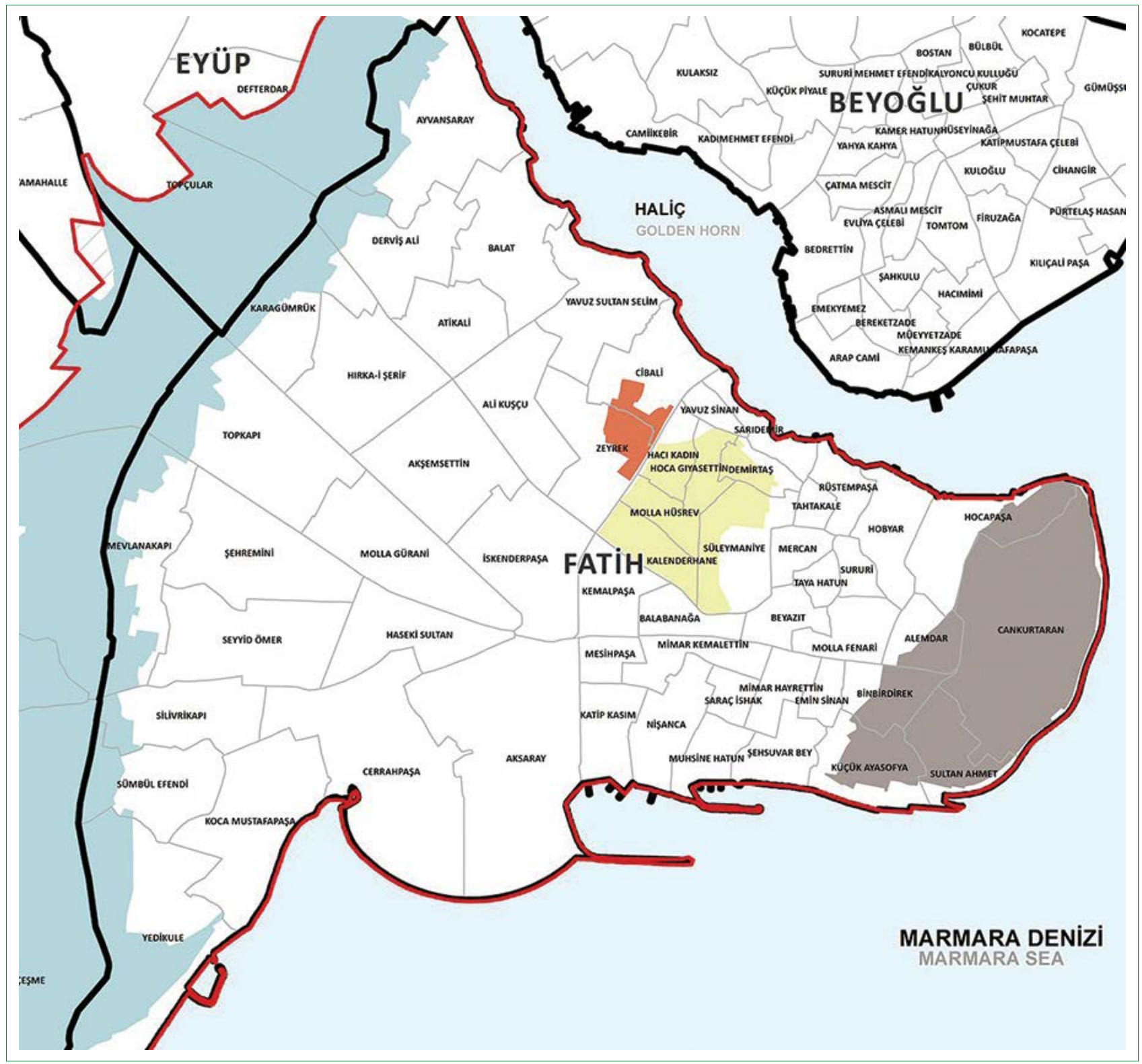

Şekil 3. Tarihî Yarımada'da UNESCO Dünya Mirası Listesi'nde bulunan alanlar [Kaynak: İstanbul Tarihi Alanları Alan Başkanlığı (http: www.alanbaskanligi. gov.trharitalar.html)].

bir çelişkinin ifadesidir. Örneğin, UNESCO, Süleymaniye ve çevresini miras olarak nitelerken yalnızca külliye yapılarını baz almamıs, o bölgedeki sivil mimari örneklerini, anıtsal yapıları, kentsel dokuyu oluşturan tüm unsurları kapsamına almıştır. Süleymaniye'nin karşısında yer alan Zeyrek de merkezde Molla Zeyrek Camii (Pantokrator Manastırı Kilisesi) olmak üzere, bütün çevresiyle bir bütün olarak kabul edilmiştir. Ancak İmar Barışı'nda, birçok tarihî sivil mimari örneği yapı ve çok sayıda kültürel ve tarihî değer barındıran Zeyrek, istisna olarak görülmemiştir. Bu ayrımın hangi gerekçeye dayandırıldığııın düzenlemede belirtilmemiş oluşu, düzenlemeye dair aydınlatılmamış konulardan sadece biridir.
İstanbul Tarihî Alanları Alan Yönetimi Başkanlığı'nın hazırladığı İstanbul Tarihî Yarımada Yönetim Planı'nda bulunan kültür varıłkları haritası (Şekil 4), Tarihî Yarımada'nın kültürel mirası konusunun bütüncül bir yaklaşımla ele alınması gerektiğini gösterir niteliktedir. Haritadaki yeşil renkli kısımlar, anıt eserleri; bordo renkli alanlar ise sivil mimari örneklerini göstermektedir. İki rengin de yarımadanın neredeyse her bölgesinde görülmesi, yarımada ile ilgili tüm koruma düşüncelerinin bütüncül bir yaklaşımla ele alınması gerektiğini gösteren bir başka gerçekliktir. Bu renklerin yoğunlaştığı ve İmar Barışı kapsamı dışında bırakılan bölgeler içinde Zeyrek-Cibali-Küçükmustafapaşa, Fener-Balat-Ayvansaray, Samatya-Yedikule, Yenikapı-Ge- 


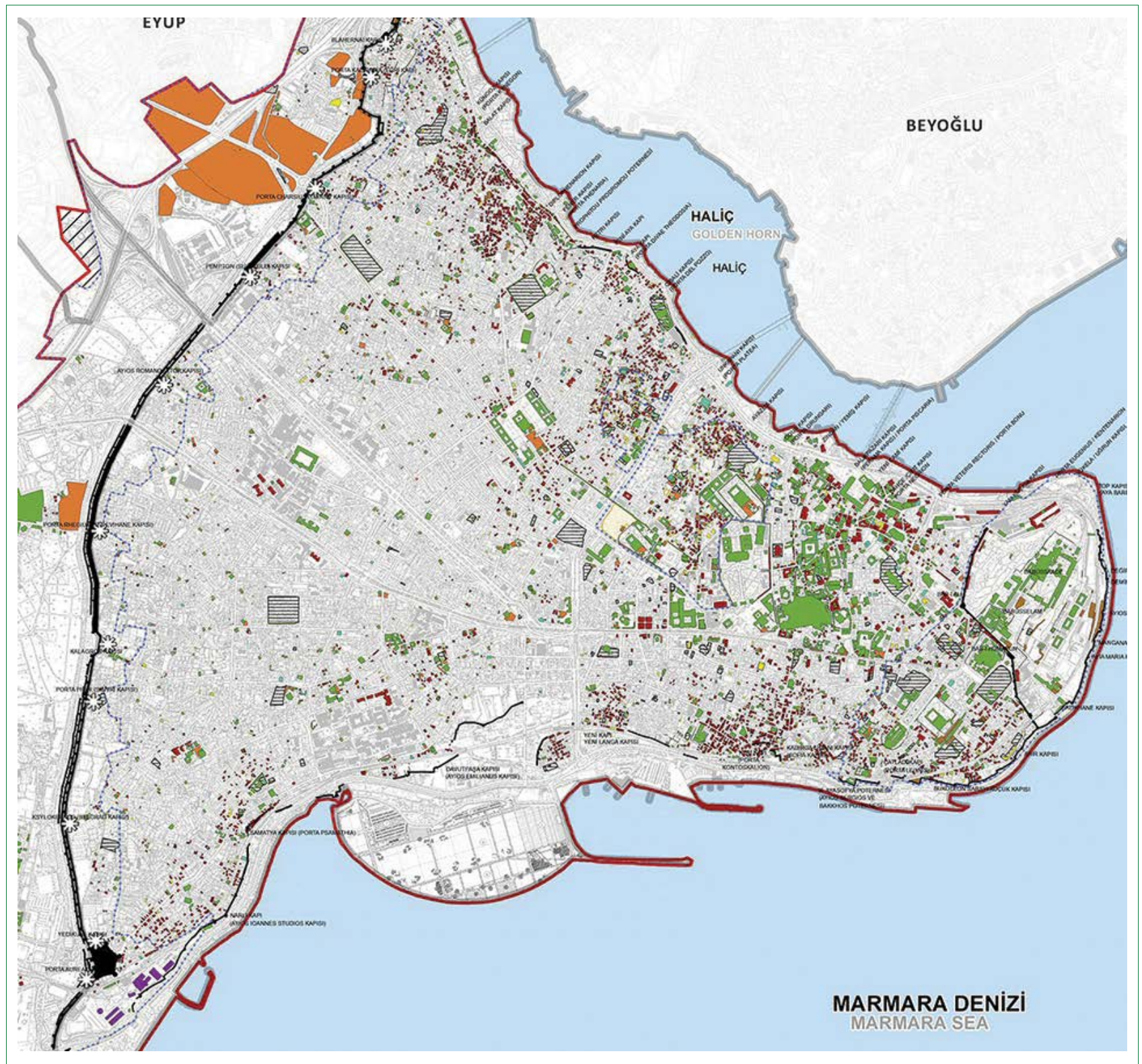

Şekil 4. Tarihî Yarımada'daki kültür varlıkları [Kaynak: İstanbul Tarihi Alanları Alan Başkanlığı (http: www.alanbaskanligi.gov.trharitalar.html)].

dikpaşa-Kumkapı-Kadırga-Küçükayasofya-Cankurtaran hattı, kültür varlıkları açısından yüksek seviyede değer arz eden bölgeler olarak öne çıkmaktadır.

Fatih ilçesinin, bir başka deyişle Tarihî Yarımada'nın tamamının sit alanı oluşu da üzerinde durulması gereken bir başka noktadır. Bu sit alanı; kentsel-tarihî sit alanı, kentsel-arkeolojik sit alanı ve I. derece arkeolojik sit alanından meydana gelmektedir. Şekil 5'te görülen ve Topkapı Sarayı'nın merkezde yer aldığı kırmızı renkli bölge, I. derece arkeolojik sit alanı; Sultanahmet Camii'nin merkezde yer aldığı sarı bölge, kentsel-arkeolojik sit alanı; gri bölge ise kentsel-tarihî sit alanıdır. Ancak İmar Barışı düzenlemesinde bu bütünlük de göz ardı edilmiştir. Örneğin, sarı bölgenin, yani kentsel-arkeolojik sit alanının çok büyük kısmı istisnanın dışında bırakılmıştır. Büyük Bizans Sarayı yapılarını barındıran bu bölgede hâlen keşfedilmeyi ve gün yüzüne çıkartılmayı bekleyen sayısız yapı, kalıntı, eser bulunmaktayken istisna sınırının bu durum yok sayılarak belirlenmesi, bu değerlerin zarar göreceği birçok uygulama ile karşılaşılmasının yolunu açmakta olup bu, üzerinde düşünülmesi gereken bir konudur.

İnsanların taşınmazlar üzerindeki hatalı tasarrufları, nesiller boyu sürecek olumsuz etkilere sebep olabilmektedir (Tekeli, 2009c, s.67). Taşınmazlar üzerindeki bu hatalı tasarruflar bir deprem ülkesi olan Türkiye'de sık sık tartışmalara konu olmak- 


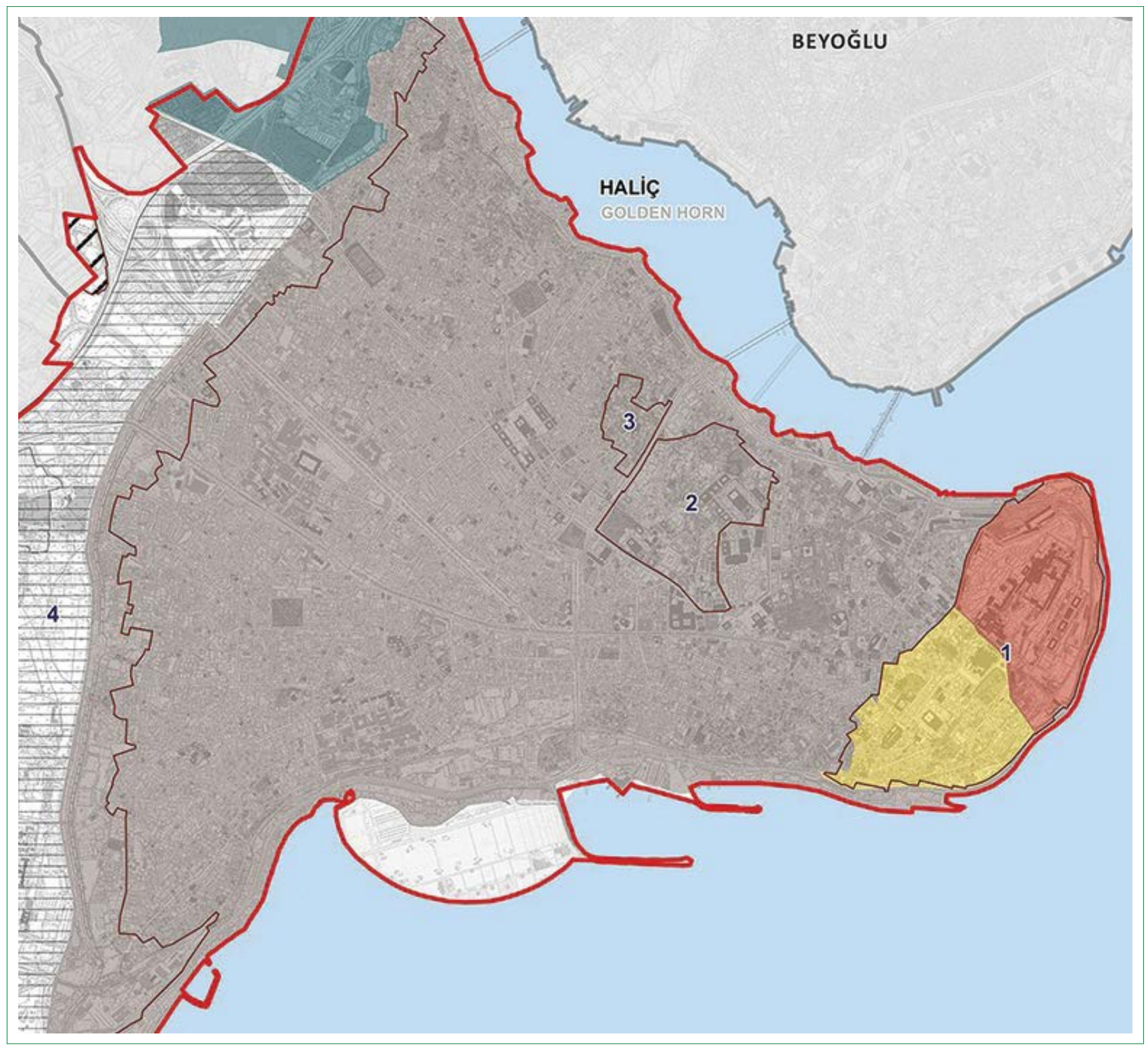

Şekil 5. Tarihî Yarımada'daki sit alanları [Kaynak: İstanbul Tarihi Alanları Alan Başkanlı̆ıı (http: www.alanbaskanligi.gov.trharitalar.html)].

tadır. 6 Şubat 2019'da İstanbul'un Kartal ilçesinde kendiliğinden çöken binada 2I kişinin hayatını kaybetmesi ve 26 Eylül 2019'da Silivri'de yaşanan 5.8 büyüklüğündeki deprem, bu tartışmaların artarak devam etmesine neden olmuştur. 1992 yılında yapılan ve zemin+5 kat iznine rağmen 1998 yılında 3 kaçak kat ile yükseltilen bina için çökmeden önce İmar Barışı kapsamında Yapı Kayıt Belgesi başvurusu yapılmış oluşu (TMMOB, 2019), İstanbul'daki yapı stokunun taşıdığı riskleri göstermesi bakımından çarpıcı bir örnektir. Fatih özelinde ise Fatih Belediyesi'nin resmî internet sitesinde yer alan habere göre ilçede İmar Barışı'na yoğun bir ilgi olduğu yönündeki haber, ilçedeki yapı stokunun risk potansiyelini göstermesi açısından açıklayıcı bir veridir (Fatih Belediyesi, 20I8). Bunun yanı sıra, Fatih'te nüfusun yoğunlaştığı mahallelerin İmar Barışı kapsamında olan mahalleler oluşu da bu mahallelerdeki kaçak yapı stoku ve nüfus düşünüldüğünde tehlikeli bir durum ortaya çıkarmaktadır.

Şekil 6'da 57 Fatih mahallesi sınırı görülmekte olup; sarı renkli mahalleler 0-2000 kişi, kırmızı renkli mahalleler 200I-7000 kişi, mavi renkli mahalleler 700 I-15000 kişi, gri renkli mahalleler I500 I-30000 kişilik nüfuslar barındırmaktadır. Bu yoğun nüfuslu mahallelerde çok sayıda İmar Barışı başvurusu yapılmış olması, bu mahallelerdeki kaçak yapı yoğunluğunu ortaya koymakta, insanların can güvenlikleri ve kültür varlıklarının korunabilmesi adına büyük bir riskin varlığına işaret etmektedir.

İmar Barışı'nın yaratacağı olası sorunların en önemlisi insan sağlığı ve can güvenliğidir. Büyük İstanbul Depremi'nin yak- 


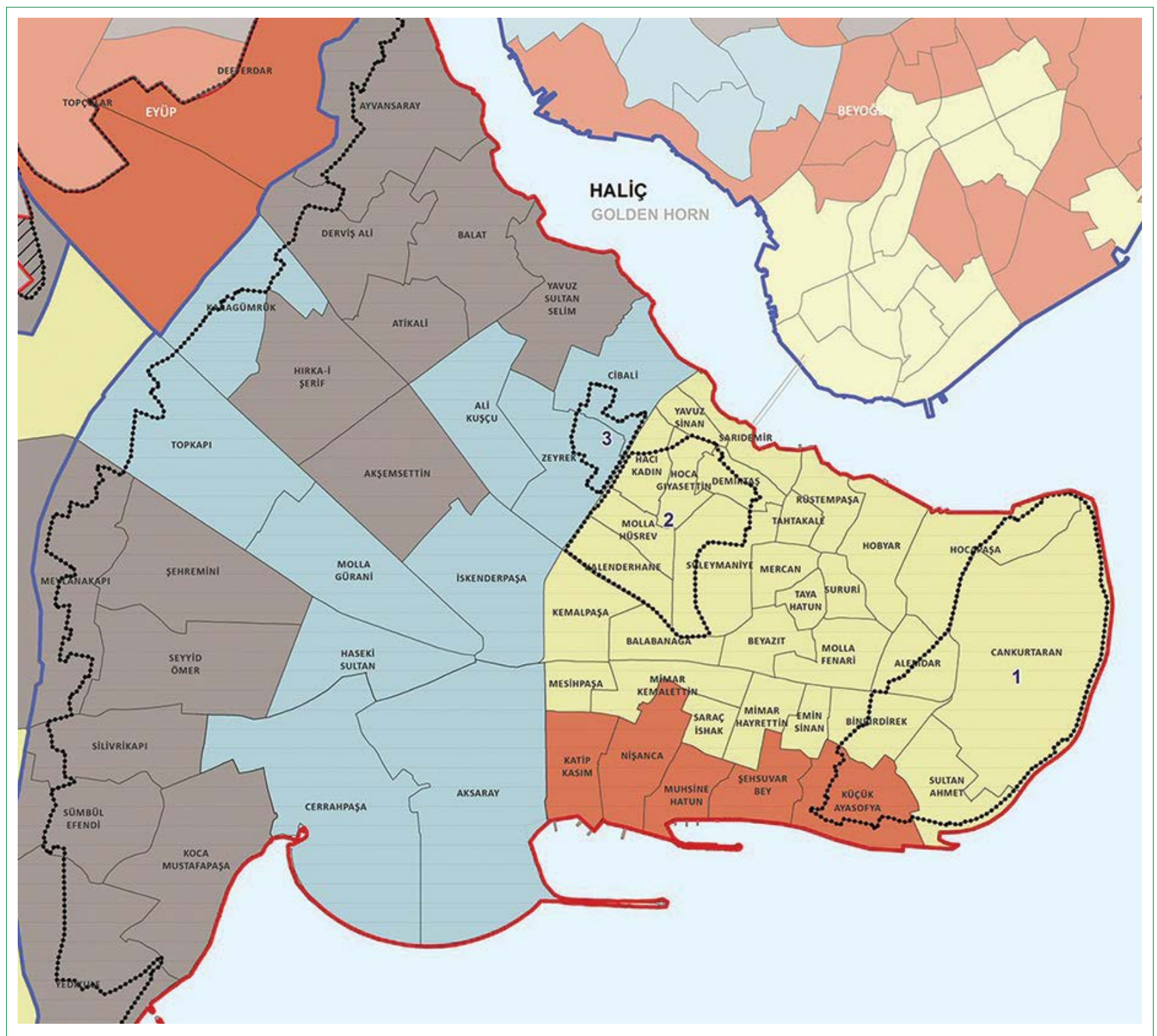

Şekil 6. Tarihî Yarımada’da 2014 yılına ait nüfus yoğunluğu [Kaynak: İstanbul Tarihi Alanları Alan Başkanlı̆ı̆ (http: www.alanbaskanligi.gov.trharitalar.html)].

laşmakta olduğu bilinirken, ülkenin konut stokunun güvenliğinin sağlanması gerekliliği, özellikle hükümetin kentsel dönüşüm odaklı söylemlerinde sıkça vurgulanan bir konudur. AK Parti'nin 2018 yılında paylaştığı "Cumhurbaşkanlığı Seçimleri ve Genel Seçimler Seçim Beyannamesi”nde "Kentsel Dönüşüm ve Konut”, "Şehircilik ve Yerel Yönetimler”, "Mekân Planlaması ve İmar", "Afet Yönetimi” gibi başlıklar bulunması ve bu bağlamda konut güvenliği ve kentsel dönüşüm gündeminin detaylandırılması, ilgili söylemlerin önemli bir tezahürüdür (AK Parti, 2018). Ancak uygulamada bu gerçeklikle çelişki yaratan düzenlemeler yapılıyor oluşu, depremin ve yaratacağı olası tahribatın göz ardı edildiğini de göstermektedir. Kaçak katlar ile yükseltilmiş binaların kendiliğinden yıkılabildiği bir ortamda, büyük ölçekli bir depremin mevcut yapılarda yaratacağı yıkım ve tahribat birçok can kaybına da sebebiyet verecektir.
Bu büyük tehdit ortadayken ve riskli yapıların vakit kaybetmeden yıkılarak yeniden yapılması ya da mevcut durumlarının düzeltilmesi gerekirken, yapıların ömrünü kısaltan eklerin imar aflarıyla yasal hâle getirilmesi hem bu dönüşüm sürecini imkânsız hâle getirmekte hem de bundan sonraki olası kaçak kat uygulamalarını daha mümkün hâle getirmektedir. Özellikle Fatih gibi geniş boşluklara sahip olma konusunda yetersiz ilçelerde yapı stokunun güvenliği daha çok önem arz etmekteyken, merkez kaynaklı düzenlemelerin, yapılması aciliyet arz eden dönüşüm ve iyileştirmelere engel teşkil etmesi önemli bir sorun olarak öne çıkmaktadır.

İmar Barışı alanında da faaliyet gösteren bir mimarlık ve inşaat şirketinin kendi internet sitesinde, Tarihî Yarımada'da danışmanlığını yaptıkları Yapı Kayıt Belgesi alımı süreçlerine dair 


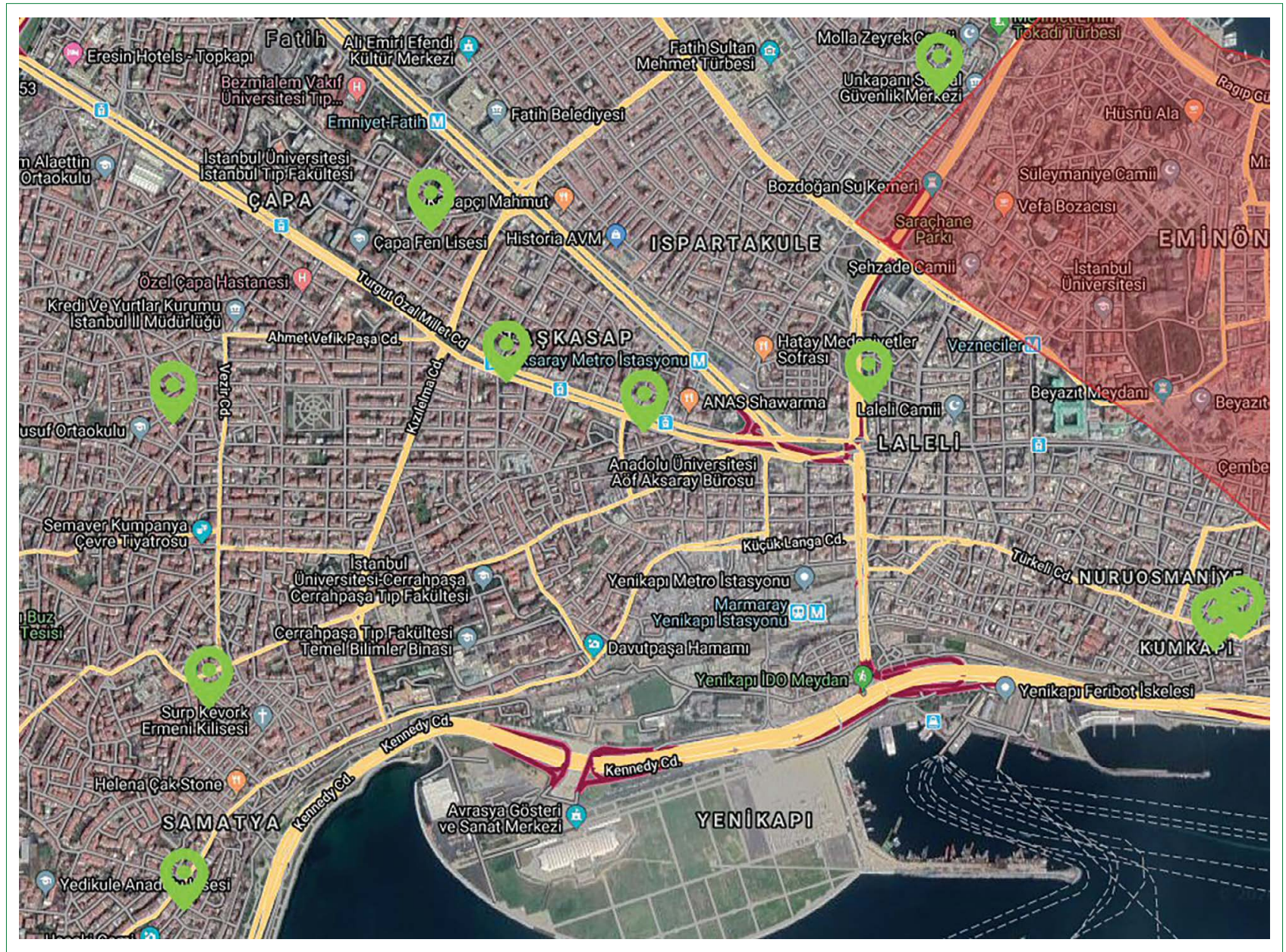

Şekil 7. Bir mimarlık ve inşaat şirketinin danışmanlığını yaptığı Yapı Kayıt Belgesi alım süreçlerine konu olan binaların Tarihî Yarımada'daki konumları (Kaynak: https: imarbarisimiz.com).

paylaştıkları bilgiler ve söz konusu yapıların ilçe içerisindeki konumları, İmar Barışı'na gösterilen ilginin ilçenin tümüne yayıldığını göstermesi bakımından çarpıcıdır (Şekil 7).

Aynı şirket, Yapı Kayıt Belgesi başvurularını sonuçlandırdığını açıkladığı yapıların görüntü ve konum bilgilerini de şeffaf bir şekilde paylaşmıştır. Bu örneklerden birisi, Fatih'in Kocamustafapaşa Mahallesi'ndeki Iftariye Sokak'ta yer alan ve 1198 ada 32 parselde bulunan yapıdır (Şekil 8). Bu yapı, görselde de tespiti yapılabilecek ekleriyle birlikte artık yasal hâle gelmiştir. Sıkışı bir muhitte yer alması, komşu binalarla bitişik nizam durumu ile hem içinde oturanlar hem de çevresi için risk taşımaktadır.

Şirketin paylaştı̆̆ı bir başka örnekte ise bir yapının yenilenip otel yapılması söz konusudur. Fatih, Şehsuvar Bey Mahallesi, Kumluk Sokak, I77 ada I parselde yer alan yapının baştan aşağı yenilendiği ve en üstteki sonradan eklendiği belli olan derme çatma katın bütünüyle bir kata çevrildiği görülmektedir. Bu yapı, söz konusu şirketin beyanına göre İmar Barışı'ndan faydalanmıştır. Günümüzde ise otel olarak faaliyet göstermektedir (Şekil 9).
Tarihî Yarımada'nın çoğu mahallesi, izinsiz ek ve katların sıkça görüldüğü yapılardan oluşmaktadır. Bu bireysel uygulamalara tescilli yapılarda da, son $60-70$ yılda yapılan apartmanlarda da yaygın olarak rastlanmaktadır. İlçenin nitelikli sivil mimari örnekleri ve bu yapıların taşıdığı riskleri göstermesi açısından, bu örneklerin yoğun olarak yer aldığı mahallelerde bazı yapılar fotoğraflanarak belgelenmiştir (Şekil I0, II). Sahip oldukları kimlikle çabucak dikkat çeken bu özel yapılar, Tarihî Yarımada'nın geçmişi ve bugünü açısından büyük önem arz etmektedir. Ancak çeşitli dönemlerde izinsiz bir şekilde yapılan ekler ve katlarla bu yapılara fiziksel ve estetik anlamda büyük zararlar verilmiştir. İmar Barışı gibi düzenlemeler, bu riskli ve olumsuz durumların düzeltilmesini zorlaştırmaktadır.

İmar Barışı'nda deprem konusunun sağlıklı bir şekilde göz önüne alınmadığını gösteren bir duruma da Özkaya Özlüer dikkat çekmiş, İmar Kanunu'nun geçici 16. maddesinin 10. fıkrasının son cümlesinde yer alan "yapının depreme dayanıklılığı hususu malikin sorumluluğundadır" ifadesinin Yapı Kayıt Belgesi alınması sürecinin en tartışmalı sonuçlarından biri 


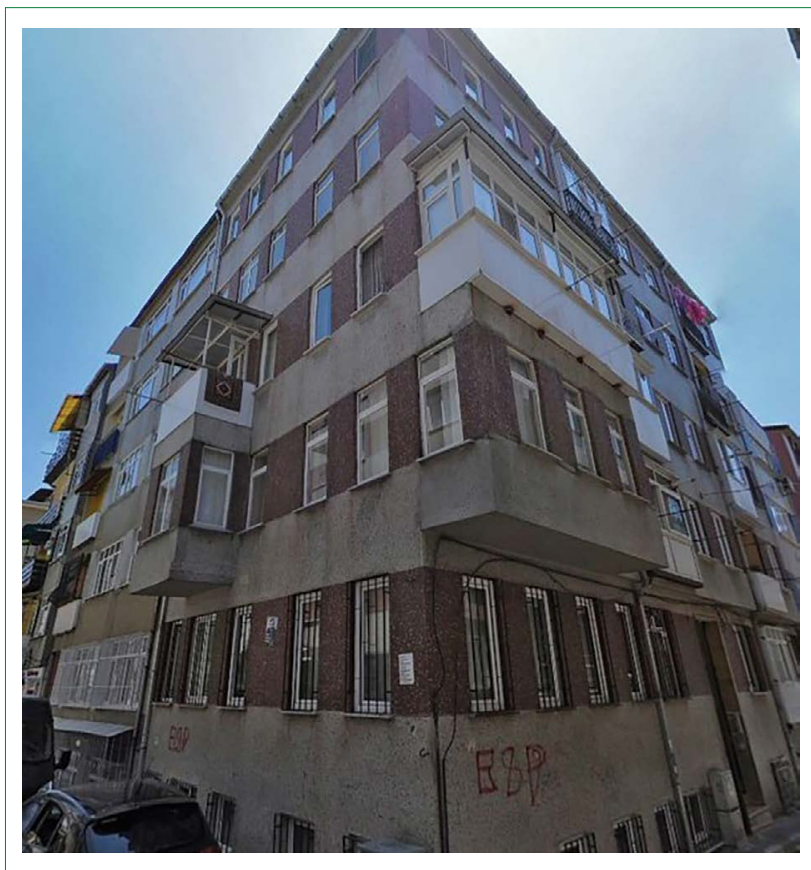

Şekil 8. Fatih'te söz konusu şirketin Yapı Kayıt Belgesi alınmasını sağladığı, I I 98 ada 32 parselde bulunan bina (Kaynak: https: yandex.com.trharita).

olduğunu ifade etmiştir. Yazara göre burada kanun koyucu, Yapı Kayıt Belgesi alınan yapıların depreme dayanıklılığı ile ilgili olarak sorumluluğun yapı sahibine geçtiği izlenimi vermektedir ve buna karşın, Yapı Kayıt Belgesi alınan yapılarla ilgili idarenin mali sorumluluğu ve idarenin denetim yükümlülüğü ortadan kalkmış olmamaktadır. Yazar burada idarenin kamu düzenini sağlamak üzere kolluk yetkilerinin asli sahibi olduğuna ve bu yetkileri kapsamında idare sorumluluğunu özel kişilere devredemeyecek oluşuna vurgu yapmıştır (Özkaya Özlüer, 2018, s.335).

İlçenin bazı noktalarında kaçak katların neredeyse yapının orijinali kadar yükselmiş oluşu, yalnızca o yapıda yaşamlarını sürdürenlerin değil, komşu yapılarda bulunanların da hayatlarını risk altına sokmaktadır. Fatih'in gün içinde diğer ilçelerden gelen insanlarla birlikte yoğunluğunun önemli ölçüde artması, yalnızca ilçede ikamet edenlerin değil, herhangi bir nedenle gün içinde bu ilçeye gelen insanların da olası bir afette yüksek risk altında olacağını göstermektedir. İmar Barışı'nın, kanuna aykııı da olsalar bir şekilde var olmuş yapıların ortadan kaldırılmasının büyük bir maddi kayba yol açacağı belirtilerek hayata geçirilmiş olması, olası bir depremin yıkıcı etkisinin yaratacağı maddi ve manevi kayıpların çok daha fazla olacağı gerçeği karşısında da çelişki yaratmaktadır.

Risk taşıyan bir başka unsur ise ilçenin neredeyse her noktasında bulunan kültür varlıklarıdır. Çok yaygın bir şekilde görülen kanun dışı ekler, tüm bu kültür varlıklarını, Fatih'in, İstanbul'un, Türkiye'nin sahip olduğu kültür mirasını da doğrudan tehdit etmektedir. Örneğin, etrafları yapılarla çevrili durumda olan külliyeler risk altındadır. Çeşmeler, hamamlar, medreseler, kütüphaneler, kiliseler, görülür hâldeki OsmanI ve Roma kalıntıları, koruma altındaki yer altı zenginlikleri, sarnıçlar ve diğer kalıntılar başta olmak üzere tüm eserler, etraflarındaki yoğun kaçak yapılaşmadan doğrudan etkilenebilecek vaziyettedir. Korunmaları için ulusal ve uluslararası alanda sayısız düzenlemenin yapıldığı, merkezî ve yerel yönetimle-

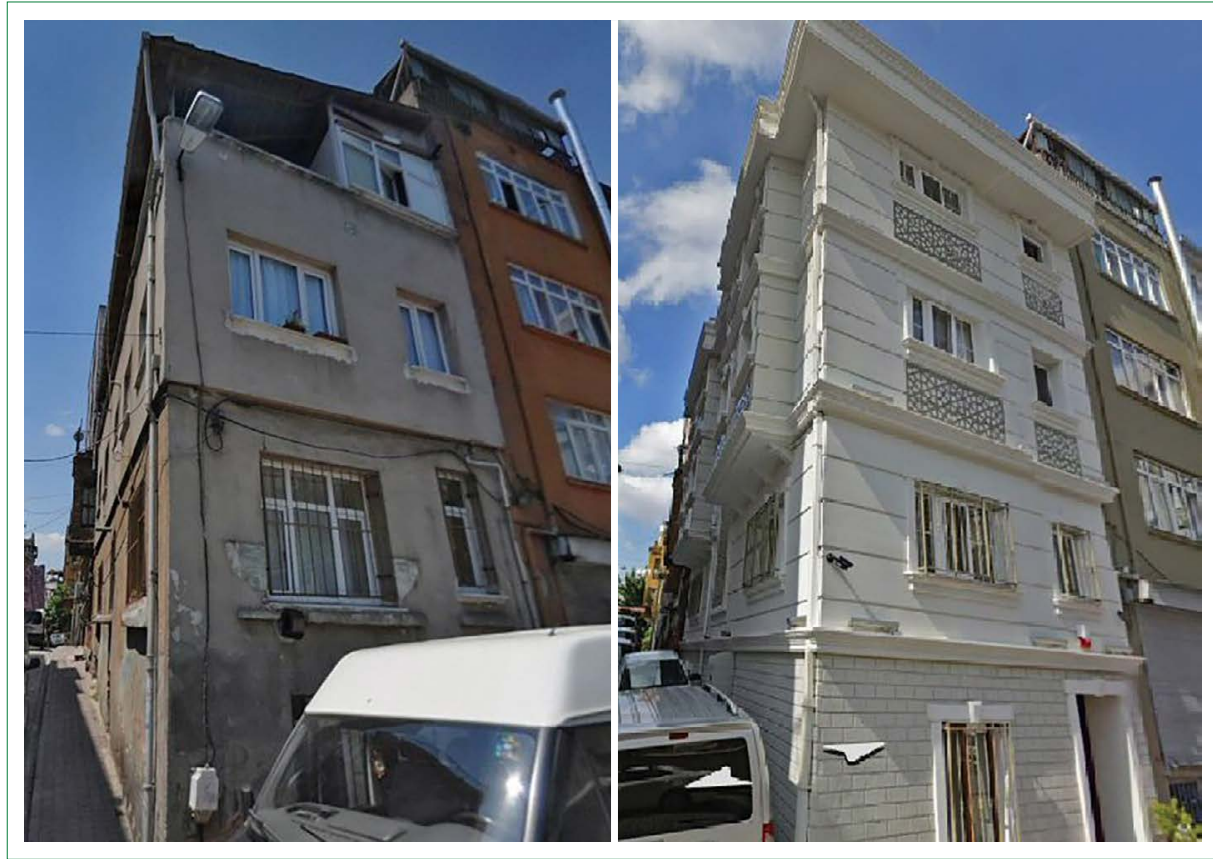

Şekil 9. Fatih'te, I77 ada I parselde bulunan bina (Kaynak: https: yandex.com.trharita). 


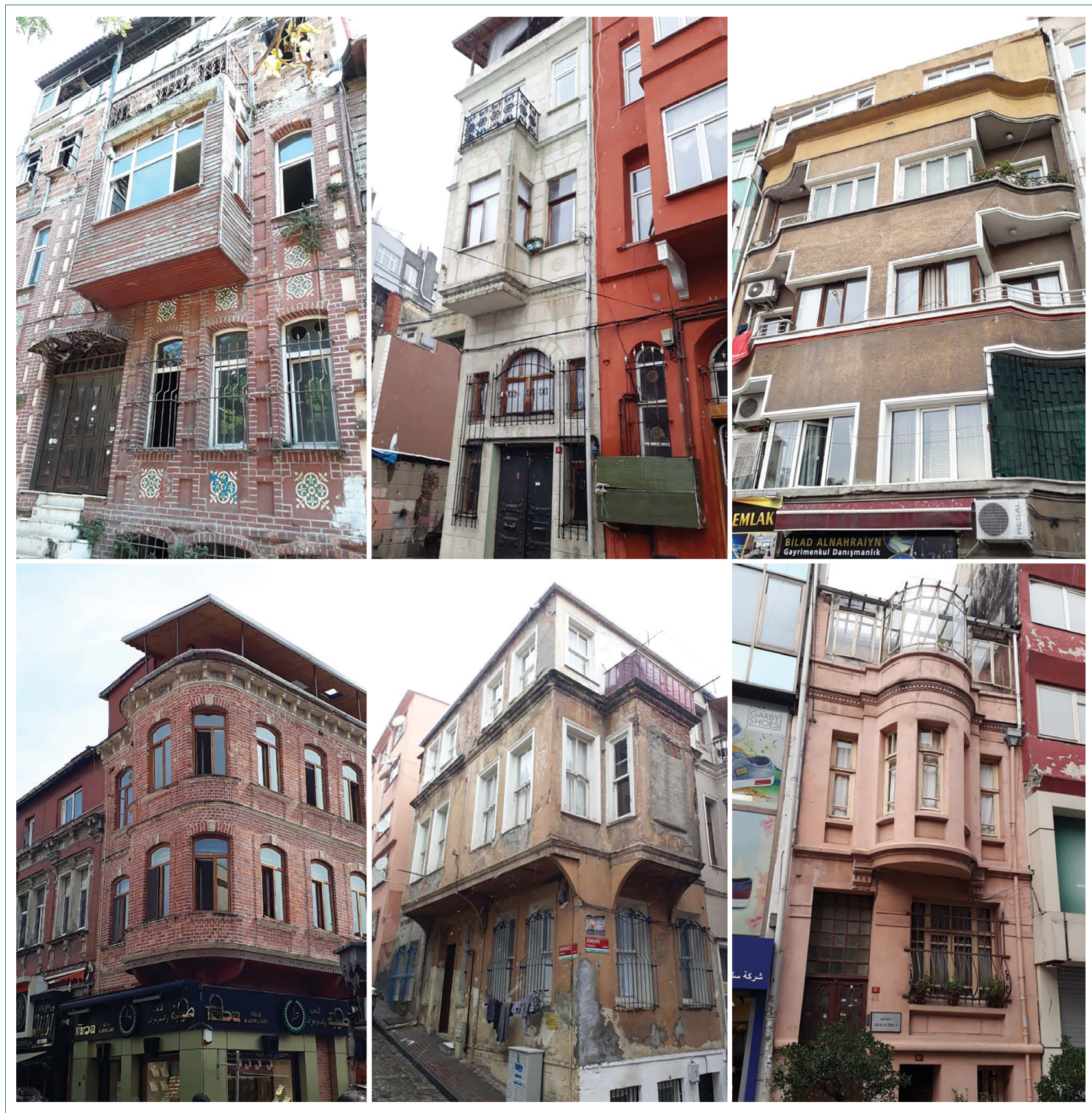

Şekil I0. Fatih'te, çıkılan katlarla orijinallikleri bozulmuş sivil mimari örnekleri. Yapıların bulunduğu semtler, üst sıra, soldan sağa: Yenikapı, Fener, Horhor; alt sıra, soldan sağa: Fatih, Balat, Beyazıt. Kaynak: Yazarın Kişisel Arşivi, 2019.

rin büyük çabalar harcadığı, akademisyenlerin ve gazetecilerin üzerlerinde çalışı̆̆ı bütün bu kültür mirasının bütüncül bir anlayışla korunması gerekirken, bu durum yok sayılarak uygulamaya sokulan İmar Barışı ile tüm bu çabalar bir anlamda boşa gitme sürecine girmiştir.

Son yıllarda tarihî kent merkezlerinin ve özelde de Tarihî Yarımada'nın kendine has kentsel dokularının yerli ve yabancı turistlerin ilgisini çektiği bir ortamda, bu dokulara verilmiş za- rarların yasal hâle gelmiş olması, gelecekte de verilecek zararların bir anlamda önünü açmıştır. Bu nitelikli alanlar üzerindeki ilgi artmışken, İmar Barışı uygulamasıyla söz konusu olacak tahribat, birçok kazanımı yok edecektir.

Günümüzde İstanbul'da yalnızca Tarihî Yarımada değil, diğer tarihî kent merkezlerimiz olan Beyoğlu, Beşiktaş, Kadıköy, Üsküdar gibi ilçeler de nitelikli kentsel dokulara sahiptir. Ancak Tarihî Yarımada gibi bu ilçelerde de kanun dışı uygulama- 

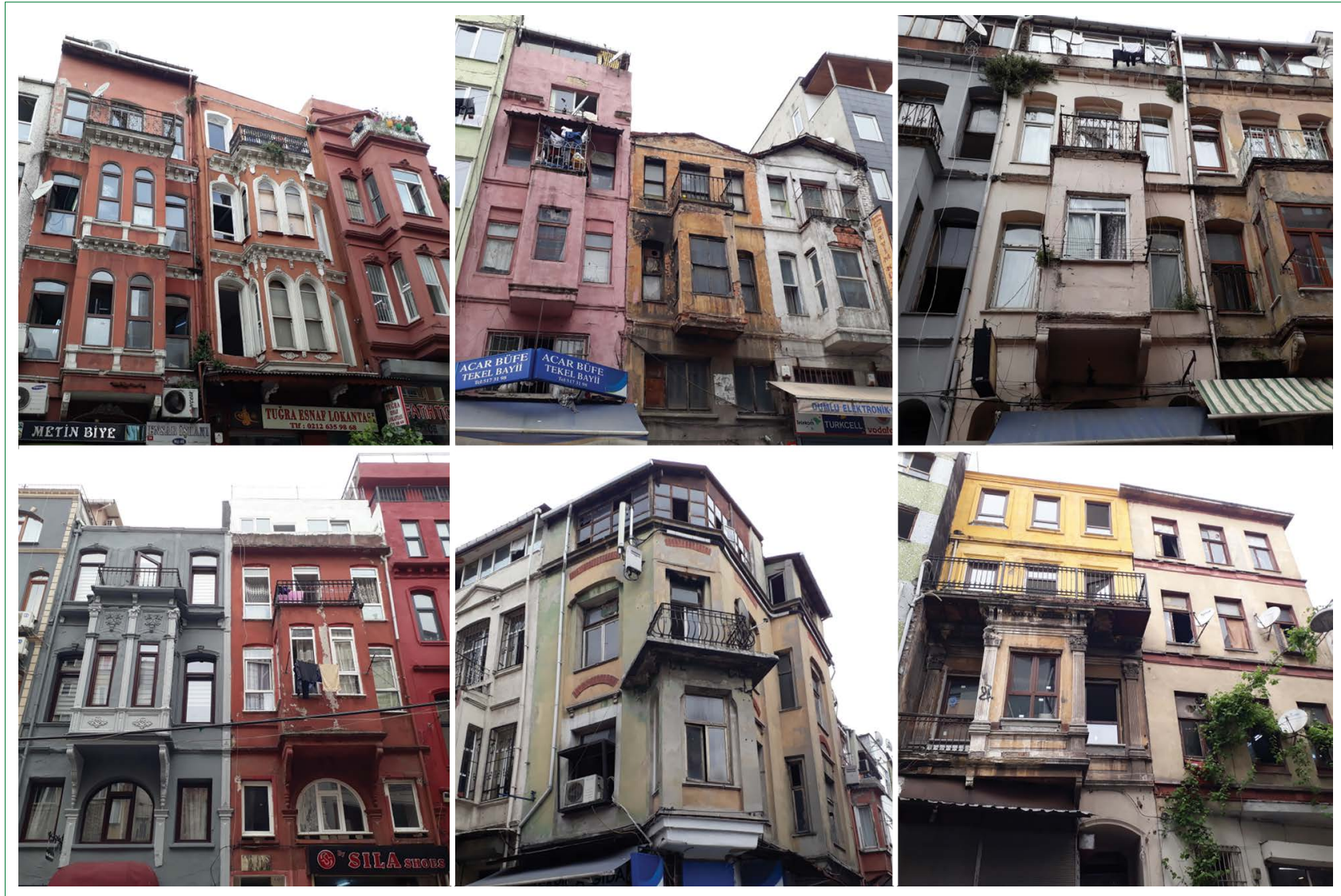

Şekil II. Fatih'te, sonradan çıkılan katlarla orijinallikleri bozulmuş sivil mimar örnekleri. Yapıların bulunduğu semt, Gedikpaşa (Kaynak: Yazarın Kişisel Arşivi, 2019).

lar neredeyse her sokak ve caddede görülmekte, bu durum da insan sağlığı ve kent estetiği gibi konularda büyük sorun yaratmaktadır. Tekeli, her yapının mimarisinin ve görünüşünün kamusal bir mal olduğunu belirtmekte, insanların mülk sahibinin verdiği kararla gerçekleşen binanın dış görünüşünü yaşamları sırasında oradan gelip geçerken tüketmekte olduklarını, bu nedenle de çevrenin görüntüsünü bozan bir yapının orada yaşayanların yaşam kalitesini etkilediğini öne sürmektedir (Tekeli, 2009b, s.268-269).

Merkezî yönetimlerce yapılan bazı düzenlemelerin, yerleşim yerlerinde birçok soruna sebebiyet verebildiği, İmar Barışı düzenlemesiyle de görülmüş durumdadır. Bu düzenlemeler, bizzat merkez eliyle çizilen yasal sınırlar, koruma çabaları ve uygulamalarıyla da çelişmektedir. Bunun yanı sıra, ilçe belediyelerinin plan ve programları dahilindeki öncelik ve uygulamalarıyla da örtüşmemektedir. Fatih Belediyesi'nin yayınladığı son stratejik plan olan 2020-2024 dönemi stratejik planında ilçe belediyesinin vizyon olarak belirlediği "Medeniyetlerin ve Türkiye'nin vitrini olan Fatih'i; eşsiz mirasına sahip çıkarak, yaşam kalitesi yüksek, kültürel, tarihî, turistik ve ticari merkez yapmak" cümlesi (Fatih Belediyesi, 2020), İmar Barışı'nın gerçekliğiyle zıtlık arz etmektedir. İlçenin bu hedefine ulaşmasının, ilçenin neredeyse tümüne etki edebilme potansiyeline sahip olan İmar Barışı karşısında zora girmesi kuvvetle muhtemeldir. Yine İstanbul Tarihî Alanları Alan Yönetimi Başkanlığı'nın hazırladığı İstanbul Tarihî Yarımada Yönetim Planı'ndaki birçok ilke, hedef ve önceliklerin de İmar Barışı'nın getirisi olan olumsuz etkiler karşısında hükümlerinin kalmadığı ortadadır.

\section{Sonuç ve Öneriler}

İmar Barışı, Türkiye'nin kentleşme sürecinde uygulanmış olan ilk imar affı değildir. Mevcut planlamaların yetersizliği, denetimsizlik, imara aykııı uygulamalar karşısında gerekli yaptırımların uygulanmaması gibi sebepler nedeniyle kentler kontrol edilemez bir hızla sıkışmış ve genişlemiştir. Araziler hızlı bir şekilde dolmuş, mevcut yapıların ise kat sayıları artış göstermiştir. Büyüyen yapı stokunun önemli bir kısmı kanuna aykırı yapılardan oluşmuştur. Bu durum neticesinde de merkezî yönetimler af düzenlemelerini devreye sokmuştur. Afların tekrar eden bir süreç izlemesi, arazi ve mülk sahiplerinin kanun dışı yollara sapmasını kolay hâle getirmiş, sürecin sonunda yeni bir imar affı çıkabileceği yönündeki inançlarını korumalarına sebep olmuştur. 
İmar aflarının uzun yıllardır belli periyotlar dahilinde merkezî yönetimler eliyle kanunlaştırılması, vatandaşların nasıl olsa af çıkacağı düşüncesiyle mevcut binalarını büyütmelerine, imar izinleri olmaksızın belli arazilerde imara aykırı yapılar inşa etmelerine neden olmuştur. Gelinen noktada ise 2018 yılında kanunlaşan İmar Barışı düzenlemesi ile birlikte tüm bu yapıların yasal hâle getirilmesi mümkün olmuştur. Giritlioğlu ve Özden (2020, s.280) düzenlemenin doğrudan bir mülkiyet hakkı da tanımadığını, kalıcı bir çözüm sunmadığını ve bir pansuman niteliği taşıdığını, toplumun yaşam kalitesini olumsuz yönde etkilediğini, can ve mal güvenliklerini tehdit ettiğini vurgulayarak düzenlemenin aksak yönleri üzerinde durmuştur.

Tarihî Yarımada özelindeki kanundan muaf bölgenin sınırları birçok çelişkiyi beraberinde getirmiştir. 2. Dünya Savaşı'ndan itibaren önemi kademe kademe artmış olan ve birçok uluslararası kurumun desteği neticesinde hayata geçirilen düzenlemelerle somut kilınan kentsel koruma olgusu ülkemizde de son yıllarda büyük ölçüde benimsenmiş, bu bağlamda birçok resmî girişim ve düzenleme yapılmıştır. Ancak Tarihî Yarımada'da söz konusu sınırlama, kentsel korumanın ilkelerine aykırılık teşkil etmekte, bölgenin bütünlüğüne zarar vermekte, birçok resmî kurumun koruma politikalarına engel yaratmakta, yürürlükte olan yönetmeliklerle uyum göstermemektedir. Makale akışında da sıklıkla atıf yapılan İstanbul Tarihî Alanları Alan Başkanlığı'nın İstanbul Tarihî Yarımada Yönetim Planı da bu noktada öne çıkmaktadır. UNESCO Dünya Mirası Komitesi ve ICOMOS'un karar ve tavsiyeleri bu planın oluşmasında kritik önemdedir. Bu plan ile birlikte İstanbul Büyükşsehir Belediyesi bünyesinde Kültür Varlıkları Daire Başkanlığının kurulması, Koruma Uygulama ve Denetim Müdürlüğü (KUDEB) ve Kültürel Miras Koruma Müdürlüğünün yeniden yapılandırılması, Dünya Mirası alanı olan Kara Surları dışındaki tampon bölgenin genişletilmesi ve daha birçok uygulama hayata geçirilmiştir. İstanbul Tarihî Yarımada Yönetim Planı dahilinde verilen birçok karar, yarımadanın kimliği ve dokusunun korunmasına yöneliktir. Planda yer alan şu ifadeler bu çabayı doğrular niteliktedir: "Kentsel tasarım projeleri doku bütünlüğünü zedelemeyecek şekilde; sokak siluetleri ve bölge-sokak-ada-parsel-yapı ölçeğinde detayları içerecek, "Fatih İlçesi, Tarihi Yarımada Silueti" etkisi göz önünde bulundurulacaktır”, “... bölgenin geleneksel mimari karakteri göz önünde bulundurularak, doku bütünlüğünü zedelemeyecek uygulamalara ilgili Koruma Kurulu onayı ile izin verilecektir", "Korunması gerekli sivil mimarlık örneği müstakil yapılar özgün biçimi ile korunacaktır. Bu tür yapılarda, restorasyon aşamasında kat mülkiyetine geçiş ilgili Koruma Kurulu kararı ile düzenlenebilir”. Bu noktada sonuç olarak Tarihî Yarımada'ya odaklı koruma programlarının varlığı ortadayken, İmar Barışı'nda belirlenen sınırların hangi kaygı ve önceliklerden hareketle oluşturulduğunun kamuoyuna açıklanmıs olması gerekliliği ortaya çıkmaktadır. Bunun yapılmaması, kanuna dair birçok noktayı belirsiz kılmışır.
Makalenin kaleme alındığı tarihte Yapı Kayıt Belgesi başvuruları sonlanmış, birçok yapının başvurusu tamamlanmış durumdadır. Tarihî Yarımada'yı oluşturan Fatih ilçesinde çok sayıda yapı kanundan yararlanmıştır. Fatih'in yapı stoku, çeşitlilik arz eden bir yapıdadır. İlçede, geçmişten günümüze ulaşmayı başarabilmiş çok sayıda sivil mimarî örneği tescilli yapı bulunmaktadır. Bunun yanı sıra, 1950'li yıllardan sonra yapılan çok sayıda apartman mevcut olup bunların çoğu riskli yapılardır. Yapıların eskilikleri ve yeterli ölçüde mühendislik hizmeti alınmadan inşa edilmiş oluşlarının yanında izinsiz yapılan eklemelerle yükleri artmış, taşıdıkları risk yükselmiş̧ir. Bu tehlike arz eden durum, yapı stokunun önemli kısmının yenilenmesi veya güçlendirilmesi gereken ilçede insanların can güvenliği konusunda endişe verici bir durum yaratmışır. Buna ek olarak, riskli yapıların olası bir afet durumunda çevrelerine verdikleri zarar düşünüldüğünde, yaratıtıkları tehlikelerin büyüklüğü de daha iyi anlaşılmaktadır. Anıtsal yapıların, tescilli yapıların, bir diğer deyişle bütün tarihî ve kültürel miras unsurlarının Tarihî Yarımada'nın geneline yayılmış oluşu, bu değerleri de risk altında bırakmaktadır.

Geçmişten günümüze ulaşmayı başarmış sivil mimari örneklerinin yoğun olarak görüldüğü Fatih semtleri, kentsel koruma anlayışının odağında yer alan bölgelerdir. Ancak bu bölgeler aynı zamanda izinsiz yapılaşmanın, kaçak kat uygulamalarının ve çeşitli imara aykırı durumların da yoğun olarak görüldüğü yerleşim alanlarıdır. Bu bölgelerin tamamına yakını, İmar Barışı kapsamında olan, yani Yapı Kayıt Belgesi başvurusu yapabilme imkânına sahip olmuş yerlerdir. Nitekim çeşitli eklemelerle kat sayısı artmış birçok yapı, kanunun tanıdığı hak ile yasal duruma gelmiştir. Bunlarda yerleşim hâlâ sürmekte, üstelik bazıları otel olarak işlev kazanmıs durumdadır. Deprem konusunda birçok önlem alınması gereken İstanbul'da bu tarz uygulamaların insan, ekonomi ve kent bazında büyük tahribatlar yaratacağı açıktır.

Kentlerin, özellikle de tarihî kent merkezlerinin estetik görünümlerinin ve kendine has kimliklerinin korunması da kentsel korumanın önemli bir boyutunu oluşturmaktadır. Turizm konusundaki hedeflerin gerek merkezî yönetim gerekse de yerel yönetimler bazında günden güne güçlenip çeşitlendiği bir dönemde kentsel dokuların tahrip olmasına yol açacak düzenleme ve uygulamalardan kaçınılması gerekmektedir.

Amsterdam Bildirgesi'nin temeli olarak kabul edilebilecek olan "Bütünleşik Koruma", Tarihî Yarımada özelinde de benimsenmesi gereken bir anlayıştır. Bu anlayışa göre kültürel mirasın korunması kavramı, yalnızca ünlü birkaç anııı korunması ile sınırı kalmamalı, önemli yapıları içermeyen ancak bir bütün olarak tarihî ve kültürel değerleri bulunan mahalleleri de kapsamalıdır. Buna bağlı olarak da koruma, kent ve ülke planlamasının ayrılmaz bir parçası olarak kabul edimelidir (Doratlı, 2007, s. 15). Görgülü de bütünleşik korumanın önemine dikkat çekmiş, bilimsel, nesnel ve evrensel olmayan politikaların tarihî mirası sosyal, ekonomik ve toplumsal yaşama katamayacakları 
gibi kentlerin kimliğinde ve kent kültüründe tahribata sebebiyet vereceklerini ifade etmiştir (Görgülü, 2007, s.39).

İmar Barışı düzenlemesi ve kentsel koruma ilkelerinin yarattığı çelişkili durumun ve ileride ortaya çıkması kurvetle muhtemel olan sorunların kısa vadede çözülmesi kolay gözükmemektedir. İstanbul'da önümüzdeki yıllarda büyük bir deprem olacağı, konunun uzmanı olan birçok bilim insanı tarafından sık sık dile getirilmekteyken, yalnızca Fatih değil, İstanbul'un genelinde ve çevre illerde ivedilikle önlemler alınması gerekmektedir.

IIlhan Tekeli'nin makale akışında aktarılan görüşlerinde de vurgulandığı üzere planlama anlayışı, kentlerin ve kentte yaşayan insanların varlıklarını sağlıkı bir şekilde sürdürebilmeleri açısından hayati önemdedir. Bilimsel gerçekler ışı̆ı̆nda ve insan odaklı bir yaklaşımla kurgulanması gereken planlama anlayışı, devamında kapsamlı bir denetim mekanizması ile kontrol edilmeli ve plan dışı uygulamaların mümkün olduğunca engellenmesine çalışımalıdır. Bu da merkezî yönetim ve yerel yönetimlerin eşgüdüm içerisinde çalışması, sivil toplum kuruluşlarının ve üniversitelerin plan ve uygulama aşamalarında sürece katılmaları, vatandaşın görüş ve hassasiyetlerinin göz önünde bulundurulması, başka bir ifadeyle, politikaların yönetişim esaslarına uygun bir şekilde yürütülmesiyle mümkündür.

Ülkemizde koruma konusunda çok sayıda kanun yürürlükte ve birçok odak aktif olarak rol almaktayken, tüm bu sürecin önünde engel teşkil eden İmar Barışı gibi düzenlemelerin hayata geçirilmesi birçok soruna sebep olmaktadır. İmar Barışı'nı ortaya çıkmasına neden olan sorunların çözülmesinin elzem olduğu açık olmakla birlikte, kanunun hazırlık sürecinde söz konusu paydaşların fikirlerinin yeterince alınmamış oluşu, ortaya çıkan sorunların öncelikli sebebidir. İmar Barışı süreci sona yaklaşmış ise de bundan sonraki süreçte müzakereye açık bir politika yürütülmesi; kentin riskli yapı stokunun düzeltilmesi, insanların can güvenliğinin sağlanması, kentlerin kültürel mirası ve kentsel dokularının geleceğe aktarııp sürdürülebilir kılınması gibi açılardan gereklilik arz etmektedir. 


\section{KAYNAKLAR}

Ahunbay. Z. (1999). Tarihi Çevre Koruma ve Restorasyon. İstanbul: Yap1-Endüstri Merkezi.

AK Parti. (2018). Cumhurbaşkanlığı Seçimleri ve Genel Seçimler Seçim Beyannamesi. Erişim: 25.01.2021 https://www.akparti.org.tr/media/318779/24-haziran-2018-cumhurbaskanligi-secimleri-ve-genel-secimlersecim-beyannamesi-sayfalar.pdf

Beyazıt, E. \& Gül, H. \& Güneş, M. (2013). Kent Kimliği ve Kimliksizleș(tiril) en Kentler Üzerine Bir Tartışma. C. Ergun, M. Güneş ve A. Dericioğulları Ergun (Der.), Kent Üzerine Özgür Yazılar içinde (s.149-162), İstanbul: Bağlam.

Çavuşoğlu. E. (2016). Türkiye Kentleşmesinin Toplumsal Arkeolojisi. İstanbul: Ayrintı.

Çevre ve Şehircilik Bakanlığı. (2018). İmar Barışı Bilgilendirme Broşürü. Erişim:18.01.2020. https://webdosya.csb.gov.tr/db/imarbarisi/icerikler/ brosur-20180603111057.pdf

Çınar. S ve Kart. N. (2005). Tarihi Kentsel Mekanları Koruma Olgusunun Turizme Etkileri ve Sultanahmet Çevresi İçin Bir Öneri. İstanbul Üniversitesi Orman Fakültesi Dergisi. Seri:A, Cilt:55, Sayı:2, 71-86.

Çöl. Ş. (1998). Kentlerimizde Kimlik Sorunu ve Günümüz Kentlerinin Kimlik Derecesini Ölçmek İçin Bir Yöntem Denemesi. (Yayımlanmamış doktora tezi). Mimar Sinan Üniversitesi, İstanbul.

Çubuk. M. (2018). İnandığım Şehircilik. İstanbul: Cinius.

Doratlı. N. (2007). KKTC'de Tarihi Kentsel Alanların Korunmasına İlişkin Yasal Çerçeveye Eleştirel Bakış. A. Mengi (Ed.). Kent ve Planlama: Geçmişi Korumak Geleceği Tasarlamak içinde (s.13-29). Ankara: İmge.

Duru. B. ve Turan. M. (2013). Korumanın Yasal ve Yönetsel Boyutları: Bereketli Topraklardan Beton Bloklara. C. Ergun, M. Güneş ve A. Dericioğulları Ergun (Der.), Kent Üzerine Özgür Yazılar içinde (s.119-127), İstanbul: Bağlam.

Fatih Belediyesi. (2018). Erişim:23.01.2020. http://www.fatih.bel.tr/icerik/15542/fatihlilerden-imar-barisina-yogun-ilgi/

Fatih Belediyesi Stratejik Planı. (2020). Erişim:23.01.2020. http://www.fatih. bel.tr/assets/insankaynaklari/stratejikplan.pdf

Giritlioğlu. P. P. ve Özden. K. (2020). Kentsel Adalet Ekseninde İmar Afları: "İmar Barış" Üzerine Bir Değerlendirme. H. Erman, T. Öğüz, Ş. Şıpka, E. İnal, B. Baysal (Der.), Prof. Dr. Necla Giritoğlu'na Armağan içinde (255-282), İstanbul: On İki Levha.

Görgülü, Z. (2007). Kültürel Mirasımızın Korunması Üzerine Bir Kez Daha Düşünürken. A. Mengi (Ed.). Kent ve Planlama: Geçmişi Korumak Geleceği Tasarlamak içinde (s.39-46). Ankara: İmge.

Hasol. D. (2012). Ansiklopedik Mimarlık Sözlüğü. İstanbul: Yapı Endüstri Merkezi.

Keleş, R. (2019). 100 Soruda Türkiye'de Kentleşme, Konut ve Gecekondu. İzmir: Cem.

Özaslan. N. (2010). Mimari Koruma Düşüncesinin Tarihsel Gelişimi. N. Özaslan ve D. Özkut (Ed.), Mimari Korumada Güncel Konular içinde (s.1-16). Eskişehir: Anadolu Üniversitesi.

Özgünel. A. C. (2007). Kültürel Mirasın Korunması Üzerine Düşünceler. A. Mengi (Ed.). Kent ve Planlama: Geçmişi Korumak Geleceği Tasarlamak içinde (s.47-52). Ankara: İmge.

Özkaya Özlüer. I. (2018). İmar Barışı Düzenlemesine Hukuki Bir Yaklaşım. İnönü Üniversitesi Hukuk Fakültesi Dergisi, Cilt:9, Sayı:2, 313-340.

Tekeli. İ. (1990). Bir Kentin Kimliği Üzerine Düşünceler, Prof. Dr. Mübeccel Kıray'a Armağan, Marmara Üniversitesi İktisadi ve İdari Bilimler Fakültesi Dergisi, Cilt:VII, Sayı:1-2.

Tekeli. İ. (2009a). Kültür Politikaları ve İnsan Hakları Bağlamında Doğal ve Tarihi Çevreyi Korumak. İstanbul: Tarih Vakfı Yurt.

Tekeli. İ. (2009b). Akılc1 Planlamadan, Bir Demokrasi Projesi Olarak Planlamaya. İstanbul: Tarih Vakfi Yurt.

Tekeli. İ. (2009c). Kentsel Arsa, Altyapı ve Kentsel Hizmetler. İstanbul: Tarih
Vakfi Yurt.

Tekeli. İ. (2010). Türkiyénin Kent Planlama ve Kent Araştırmaları Tarihi Yaziları. İstanbul: Tarih Vakfi Yurt.

Tekeli. İ. (2013). İstanbul'un Planlanmasının ve Genişlemesinin Öyküsü. İstanbul: Tarih Vakfi Yurt.

TMMOB. (2019). Erişim:23.01.2020. https://www.tmmob.org.tr/icerik/ kartalda-yasanan-facia-siyasal-iktidarin-yanlis-imar-politikalarinin-urunudur

Türkiyede Tarihi Kent Dokularının Korunması ve Geleceğe Taşınması Sempozyumu. (2002).

UNESCO. (2011). Tarihî Kentsel Peyzaja İlişkin Tavsiye Kararı. Erişim:22.01.2020. http://www.unesco.org.tr/Pages/590/176

2863 sayılı Kültür ve Tabiat Varlıklarını Koruma Kanunu. (1983). Resmi Gazete. Sayı:18113. Erişim:22.01.2020. https://www.mevzuat.gov.tr/ MevzuatMetin/1.5.2863.pdf

3194 sayıl İmar Kanunu.(1985). Resmi Gazete. Sayı:18749. Erişim:18.01.2020. https://www.mevzuat.gov.tr/MevzuatMetin/1.5.3194.pdf

7143 sayılı Vergi ve Diğer Bazı Alacakların Yeniden Yapılandırılması ile Bazı Kanunlarda Değişiklik Yapılmasına İlişkin Kanun. (2018). Resmi Gazete.

Say1:30425. Erişim:20.01.2020. https://www.resmigazete.gov.tr/eskiler/2018/06/20180606-8.htm 